\title{
Recent land subsidence caused by the rapid urban development in the Hanoi region (Vietnam) using ALOS InSAR data
}

\author{
V. K. Dang ${ }^{1,3}$, C. Doubre ${ }^{2}$, C. Weber ${ }^{1}$, N. Gourmelen ${ }^{4}$, and F. Masson ${ }^{2}$ \\ ${ }^{1}$ Laboratoire Image Ville et Environnement, ERL7230, Université de Strasbourg, CNRS, 3 rue de l'Argonne, 67083 \\ Strasbourg CEDEX, France \\ ${ }^{2}$ Institut de Physique du Globe de Strasbourg, UMR7516, Université de Strasbourg/EOST, CNRS, 5 rue René Descartes, \\ 67084 Strasbourg CEDEX, France \\ ${ }^{3}$ Ha Noi National University of Education, 136 Xuan Thuy Street, Cau Giay, Ha Noi, Vietnam \\ ${ }^{4}$ School of Geosciences, University of Edinburgh, Drummond Street, EH10 4AR Edinburgh, UK
}

Correspondence to: V. K. Dang (dangvukhac@gmail.com)

Received: 5 July 2013 - Published in Nat. Hazards Earth Syst. Sci. Discuss.: 5 November 2013

Revised: 20 August 2013 - Accepted: 23 February 2014 - Published: 25 March 2014

\begin{abstract}
Since the 1990s the land subsidence due to the rapid urbanization has been considered a severely destructive hazard in the center of Hanoi City. Although previous studies and measurements have quantified the subsiding deformation in Hanoi center, no data exist for the newly established districts in the south and the west, where construction development has been most significant and where groundwater pumping has been very intensive over the last decade. With a multi-temporal InSAR approach, we quantify the spatial distribution of the land subsidence in the entire Hanoi urban region using ALOS images over the 2007-2011 period. The map of the mean subsidence velocity reveals that the northern bank of the Red River appears stable, whereas some areas in southern bank are subsiding with a mean vertical rate up to $68.0 \mathrm{~mm} \mathrm{yr}^{-1}$, especially within the three new urban districts of Hoang Mai, Ha Dong - Thanh Xuan and Hoai Duc Tu Liem. We interpret the spatial distribution of the surface deformation as the combination of the nature of the unsaturated layer, the lowering of groundwater in the aquifers due to pumping withdrawal capacity, the increase of built-up surfaces and the type of building foundation. The piezometric level in $Q_{\mathrm{p}}$ aquifer lowers particularly after 2008, whereas the groundwater level in $Q_{\mathrm{h}}$ aquifer remains steady, even if it loses its seasonal fluctuation in urban areas and drawdowns in neighboring water production plants. The time evolution deduced from the InSAR time series is consistent with previous leveling data and shows that the lowering rate of the surface slightly decreases till 2008 . The analysis of groundwater
\end{abstract}

levels in instrumented wells shows a correlation between the behavior of groundwater with the urban development and the acceleration of groundwater withdrawal. Also, the time variations suggest that the deformation became non-stationary, with upward and downward transient displacements related to the charge and discharge of the aquifers.

\section{Introduction}

The phenomenon of land subsidence due to the underground exploitation has accelerated over the last decades because of the increasing demand of natural resources (Johnson, 1995). The ground deformation is particularly unsettling when it occurs in large cities, where the recent intense urbanization implies growing water consumption with a significant pumping of the aquifers. This problem has been observed in many large cities such as Mexico City (Mays, 2009), Bangkok (Aobpaet et al., 2010), Shanghai (Lin et al., 2011), Venice (Brambati et al., 2003) and Las Vegas (Bell et al., 2002). The effects are significant when the urban area is situated on alluvial plains mainly composed of unconsolidated, compressible sedimentary formations. Since the 1960s, a large number of studies on land subsidence have been carried out using several methods of investigation (Poland, 1984; Galloway et al., 2000; Gourmelen et al., 2007) for a better understanding of the involved mechanisms (Holzer, 1984; ZhenDong and Ya-Jie, 2012) and its environmental consequences 
(Snelting and Bruchem, 1984; National-Research-Council, 1991; Holzer and Galloway, 2005; UNESCO, 2006). The measurement techniques quantifying the ground deformation related to ground subsidence vary from in situ techniques such as leveling (Bitelli and Russo, 1991) and extensometry (Ireland et al., 1984; Poland, 1984) to spatial techniques such as static global positioning system (Ikehara, 1994), radar interferometry (Massonnet and Feigl, 1998) and airborne lidar (Froese and Mei, 2008).

The capital of Vietnam, Hanoi City, is a good example of a quickly urbanized city in a developing country, where groundwater is the only resource of drinking water (Jusseret et al., 2010). From the beginning of the 1990s, urban development started to prosper in both socio-economic and land use aspects. With the conversion of agricultural land to urban space, several new urban districts have been created in the south and west of the city center in response to housing needs. That has led to population concentrations and intensive water extraction through several groundwater-pumping fields in these new urban districts. Moreover, three other water production plants were added in the 2002-2005 period in suburban districts during the development of the city, with a total capacity of $30000 \mathrm{~m}^{3}$ day $^{-1}$ each (PPJ et al., 2011). The lowering of the groundwater level (Montangero et al., 2007) has inevitably induced local land subsidence, causing numerous foundation failures of infrastructures, private small houses and old buildings (Ha, 2004). In the context of rapid urbanization after the regulation of Hanoi City's administrative boundary in 2008, a better understanding of the ground deformation within the new urban region delimited by the Hanoi Master Plan to 2030 and vision to 2050 appears crucial for the purpose of reasonable urban planning on the one hand, and for an application of construction engineering safety solutions in the areas affected by land subsidence on the other hand.

Previous studies based on terrestrial measurements (Nguyen and Helm, 1995; Nguyen, 2007; Dinh et al., 2008) or soil characteristics modeling (Trinh and Fredlund, 2000) highlighted that some parts of the central districts have been affected by ground deformation over the last decades. For example, the in situ measurements have pointed out that the ground surface has subsided more intensely in the city center than in its surrounding areas, especially near the groundwater extraction fields. The mean subsidence amplitude ranges from 1.4 to $41.0 \mathrm{~mm} \mathrm{yr}^{-1}$ for the 1994-2005 period (Nguyen, 2007). However, these in situ measurement methods are not appropriate for monitoring large-scale displacement such as land subsidence over an entirely new urban region, because they provide information at specific investigation points. On the contrary, measurements based on the remote technique of Synthetic Aperture Radar Interferometry (InSAR) are suitable for providing subsidence magnitude over broad areas with centimetric to millimetric accuracy depending on the available data set. With this method, several studies focused on the ground deformation in central districts using sev- eral SAR images acquired by different sensors (Raucoules and Carnec, 1999; Carnec and Raucoules, 2001; Tran, 2007; Noel, 2008; Vöge, 2011). By using the conventional InSAR approach, the study of Carnec and Raucoules (2001) showed a vertical displacement of an order of $20.0 \mathrm{~mm}$ within the 1996-1998 period. However, they do not obtain an accurate velocity field over the whole new urban region, since they focused only on the city center. Also, their approach suffers from some usual key limitations of the InSAR techniques. First, the available catalog of C-band images (mainly ERS and Envisat from the European Space Agency) was too small to properly cover a long time period (Noel, 2008) and unsuitable for combining SAR images separated by reasonable spatial and temporal baselines. Second, the tropical climate generates a significant atmospheric signal in the InSAR data (Takeuchi and Yamada, 2002), particularly in the troposphere from C-band images (Zebker et al., 1997). Finally, the main limitation corresponds to the decorrelation due to the change of scattering properties of the ground, mainly related to significant vegetation within the city (Wei and Sandwell, 2010). In order to overcome this difficulty, Vöge (2011) processed one couple of L-band ALOS-PALSAR images (wavelength $23.62 \mathrm{~cm}$ ) and evidenced a maximum vertical ground displacement of $90.0 \mathrm{~mm}$ within the February 2007-June 2008 period. But this latter study, together with those ones using C-band images (ERS or Envisat), did not provide accurate deformation rates of the ground for the whole study area, for the recently urbanized areas in particular, nor over a large time period.

In this study, we apply the recent multi-temporal InSAR method, (StaMPS-MTI) developed by Hooper et al. (2007). Using a set of ALOS PALSAR's satellite L-band images, the objectives of this study are to (1) precisely map the spatial distribution of land subsidence over the 2007-2011 period by determining the vertical velocity of a maximum of data pixels, (2) describe the temporal evolution of the subsiding areas, and (3) analyze these results with respect to several related parameters, being (i) the resistance of the shallow geological layers, (ii) the extent of the new urbanized areas built during these last decades and (iii) the groundwater extraction, taking into account the locations and the extraction rate of the water pumping plants, but also the water level within the main aquifers given by a recently available data set. This corresponds to measurements at several observation wells during the 2006-2010 period collected by the Hanoi Center for Water Resources Planning and Investigation.

\section{Study area}

After the renovation (Doi Moi) in 1986, the capital of Vietnam began its economic transformation. The dynamics of economic development, together with new management policies, have rendered Hanoi City, especially the urban districts more attractive for immigrants from proximate provinces. 
Currently, this city is divided into 10 urban districts, 19 suburban districts after 4 alternate times of administrative regulation, promoting the conversion of peripheral agricultural areas to urban land with the creation of several urban districts such as Tay Ho in 1995, Thanh Xuan and Cau Giay in 1996, Long Bien and Hoang Mai in 2003 and Ha Dong in 2008 (Fig. 1). As a consequence, the population of the whole city grew from 2.431 to 3.184 million inhabitants from 1995 to 2006, while the population of the urban districts doubled from 1.082 to 2.050 million in the same period. Population growth went on to reach 6.472 million inhabitants in 2009, with a density of 1979 inhabitants $\mathrm{km}^{-2}$ and approximately 35000 inhabitants $\mathrm{km}^{-2}$ in some central districts, such as Dong Da or Hoan Kiem (GSO, 2009).

Hanoi City is located in the northwest of the Red River plain, dominated by flat relief with an elevation below $15 \mathrm{~m}$, except for the Tam Dao hills in the north and the Ba Vi mountains in the southwest, reaching up to $462 \mathrm{~m}$ and $1281 \mathrm{~m}$, respectively (Fig. 1). Currently, the $3325 \mathrm{~km}^{2}$ territory of Hanoi City $\left(20^{\circ} 35^{\prime}-21^{\circ} 23^{\prime} \mathrm{N}, 105^{\circ} 17^{\prime}-106^{\circ} 02^{\prime} \mathrm{E}\right)$ is affected by a tropical monsoon climate with a hot summer season with heavy rainfalls spanning from May to October, and a cool and dry winter season spanning from November to April. The main flow of the Red River goes through Hanoi City and splits into the Day River on the eastern side and Duong River on the western side of the city (Fig. 1). Its hydrology regime varies seasonally following the climate season: the discharge on Red River at Hanoi hydrological station reaches a maximum of $23 \times 10^{3} \mathrm{~m}^{3} \mathrm{~s}^{-1}$ (accounting for $70-80 \%$ of the annual budget) during the rainy season and a minimum of $700 \mathrm{~m}^{3} \mathrm{~s}^{-1}$ during the dry season (Luu et al., 2010). Red River plain is a small part of the Red River basin, which is controlled by the Neogene Red River fault system and is surrounded by Precambrian crystalline rocks and Paleozoic to Mesozoic rocks (Tanabe et al., 2006).

The subsoil of Hanoi City comprises the Pleistocene sediments of Vinh Phuc, Ha Noi, and Le Chi formations underlying the Holocene sediments of the Thai Binh and Hai Hung formations (Mathers and Zalasiewicz, 1999). These formations mainly consist of sediments filled in the accumulation process to form the Red River plain, in which costal deposits such as sand and clay are overlain by fluvial and floodplain deposits (Jusseret et al., 2010). Quaternary sediments directly overlay Neogene deposits and generate two main aquifers: the Holocene unconfined aquifer $\left(Q_{\mathrm{h}}\right)$ and the Pleistocene confined aquifer $\left(Q_{\mathrm{p}}\right)$, separated by an impermeable layer of clay (Nguyen, 1996b). The thickness of the $Q_{\mathrm{h}}$ aquifer varies laterally from $10.0 \mathrm{~m}$ in the north to $45.0 \mathrm{~m}$ particularly along the Red River. This $Q_{\mathrm{h}}$ aquifer is mainly used for small-scale water exploitation by dug wells or drilling shallow wells. The depth of the $Q_{\mathrm{p}}$ aquifer ranges from 10.0 to $43.0 \mathrm{~m}$ and its thickness varies from 13.5 to $62.5 \mathrm{~m}$ beneath Hanoi City. This $Q_{\mathrm{p}}$ aquifer plays a crucial role in the supply of freshwater with large pumping stations for almost all activities of the urban districts of the city

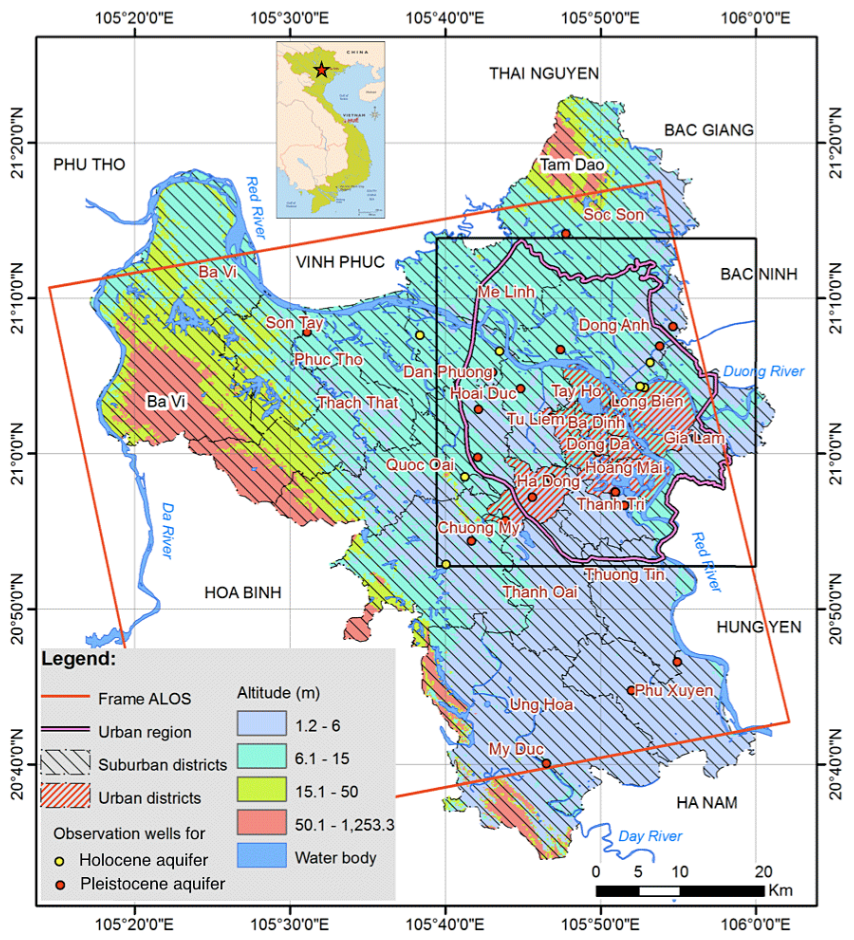

Fig. 1. Map of Hanoi City urban region, with location of urban and suburban districts (after NARENCA, 2009). The black box corresponds to the area under study with the InSAR approach in Fig. 3.

(Rau et al., 1991). The groundwater monitoring, including water level, temperature, chemical compositions in $Q_{\mathrm{p}}$ and $Q_{\mathrm{h}}$ aquifers is measured weekly through a network of observation wells: 21 wells for $Q_{\mathrm{h}}, 32$ wells for $Q_{\mathrm{p}}$ dispersed around Hanoi City (Fig. 1) by the "National Groundwater Monitoring Database" project (CWRPI, 2011). From these data sets, interpolated isocontours of the averaged groundwater level for the Holocene aquifer and groundwater piezometric head for the Pleistocene aquifer are calculated yearly by the Northern Division of Planning and Investigation for Water Resources, utilizing the commonly used GIS and Kriging interpolation methods (Bui et al., 2010).

\section{Methodology and data}

\subsection{Methodology}

Since the early 1990s, the success of the InSAR technique has been demonstrated for a large panel of applications, such as landslides, volcanic activity, glacier motion or seismic deformation (Bürgmann et al., 2000). In the case of repeat pass, the classical InSAR method allows the generation of interferograms corresponding to the phase difference. This phase difference of a single pixel corresponds to the addition of several contributions:

$\Phi \equiv \Sigma\left(\Delta \varphi_{\text {orb }}+\Delta \varphi_{\text {topo }}+\Delta \varphi_{\text {atm }}+\Delta \varphi_{\mathrm{N}}+\Delta \varphi_{\text {def }}\right)$, 
with $\Delta \varphi_{\text {orb }}, \Delta \varphi_{\text {topo }}, \Delta \varphi_{\text {atm }}$, and $\Delta \varphi_{\text {def }}$ being the phase difference due to the orbital positions, the topography, the atmosphere delay, and the ground deformation, respectively. The noise term $\left(\Delta \varphi_{\mathrm{N}}\right)$ is related to the variability of scattering, thermal noise, and data processing errors. In order to retrieve with accuracy the deformation term, a good estimate of the other contributions is necessary, based on precise data of both orbital parameters and topography. The deformation term can be expressed as the following:

$\Delta \varphi_{\text {def }}=4 \pi \Delta R / \lambda$,

with $\Delta R$ being the change of satellite-ground distance along the line of sight (LOS) direction and $\lambda$ the wavelength of the radar system.

Because of its high sensitivity to vertical displacement, the InSAR monitoring of the human-induced subsidence phenomenon became one of the main applications (e.g., Massonnet et al., 1997; Fielding et al., 1998; Galloway et al., 1998; Lazecky et al., 2010), especially in urban areas where the number of coherent pixels over time remains high (e.g., Hoffmann et al., 2001; Watson et al., 2002; Stramondo et al., 2008; López-Quiroz et al., 2009; Crosetto et al., 2010; Crosetto et al., 2013). The decorrelation noise results either from a variation of the satellite LOS direction for the two images (different look and squint angles) or from a change of the scatterer position or geometry within the resolution cell. If the decorrelation noise is too significant, the interferogram will be not suitable for analyzing the deformation. Also, in the case of high deformation rates, the deformation term $\left(\Delta \varphi_{\text {def }}\right)$ is dominant, which offers the opportunity to measure the displacement between two dates of image acquisition (Amelung et al., 1999). However, in the case of slow motion, the determination of the deformation term can be limited by the preponderance of the non-deformation terms. By stacking several interferograms of the same area, the signalto-noise ratio is increased, allowing the determination of a mean velocity of the ground over the period covered by the interferograms (Peltzer et al., 2001). This approach is effective in the case of steady-state displacements, but prevents any evidence of non-stationary deformation.

In order to overcome the temporal decorrelation due to the change of scattering properties (Zebker and Villasenor, 1992), reduce the influence of the atmosphere and measure transient displacements, multi-temporal InSAR techniques have been recently developed. The methods based on multiple acquisitions of SAR images are known as persistent scatterers (PS) and small baseline (SB). In general, these two approaches PS and SB are optimized to process different types of scatterers on the ground. The PS approach aims to process the resolution cells dominated by one single scatterer, while the SB approach aims to treat resolution cells by many scatterers without a dominant one. The PS approach takes advantage of the large energy returned by one scatterer within a resolution cell, corresponding to either rock outcrops in natural areas or man-made features such as buildings, towers, and utility poles in urban areas (Ferretti et al., 2000; Ferretti et al., 2001; Lyons and Sandwell, 2003; Kampes, 2005). For the selection of the stable pixels (or PS pixels), Ferretti et al. (2001) developed a method based on the variation of the pixel amplitude in a series of numerous interferograms particularly adapted for urban areas and fast displacement rates. Many studies have been focused on land subsidence using the former PS method (e.g., Kim et al., 2007; Stramondo et al., 2008; Cigna et al., 2012; Tung and Hu, 2012). Hooper et al. (2004) developed a method based on the spatial correlation of the phase and the amplitude, as well as suitability for natural outcrops and low displacement rates. Both of these methods require forming all interferograms with respect to a "master" image, chosen in order to both maximize the interferometric coherence of all the pairs (small spatial and temporal baselines) and co-register the interferograms. The SB method, primarily developed by Berardino et al. (2002) and Schmidt and Bürgmann (2003), overcomes the temporal decorrelation problem by using combinations of multi-look interferograms separated by short time intervals and short spatial baselines. However, Hooper et al. (2004) and Lanari et al. (2004) proposed single-look interferograms via SB algorithms and then Lanari et al. (2007), Lanari et al. (2010) and Bonano et al. (2012) used this technique to monitor the temporal evolution of the surface deformation.

In this paper, we follow the Multi-temporal InSAR method StaMPS/MTI developed by Hooper (2008) that combines InSAR PS method with SB method in order to extract the deformation signal at a larger number of pixels and to increase the signal-over-noise ratio. The selection of PS pixels is performed firstly using PS approach developed by Hooper et al. (2007), and then, a second series of interferograms are processed using SB approach in order to identify distributed scatterers (DS), for which the filtered phase does not decorrelate significantly over short time periods. Using the MTInSAR method, the deformation signal is extracted at both the PS and DS pixels, that we here call selected pixels (SP), increasing the spatial coverage of signal and eventually contributing to a better phase unwrapping. A first 3-D phase unwrapping using a statistical cost approach (Hooper et al., 2012), and then the estimate of the digital elevation model (DEM) errors by correlation with the values of the perpendicular baselines of each interferograms in order to unwrapped a second time taking into account these corrections. ALOS time-series analysis can suffer from residual DEM errors due to the frequent temporal correlation of the perpendicular baseline (Samsonov, 2010; Chen et al., 2013), however in our data set the temporal correlation of the perpendicular baseline is low and the inversion for DEM error is robust due to the temporal variability of the perpendicular baseline; we observe no DEM errors in the region of surface deformation.

Up to now, few applications of this methodology have focused on land subsidence in urban areas (e.g., Aobpaet et al., 2010; Yan et al., 2012). 


\subsection{Data}

We use a total of 22 raw SAR image scenes acquired in Lband (wavelength of $23.6 \mathrm{~cm}$ ) at level 1.0 between February 2007 and February 2011 by the Japanese sensor (PALSAR) onboard the Advanced Land Observing Satellite (ALOS) during its descending track 475 , frame 400 (Fig. 1). In order to minimize both temporal and spatial decorrelation, the selected master image corresponds to the image acquired on 25 July 2009. Using a threshold of $2000 \mathrm{~m}$ and 4 years for spatial and temporal baselines, respectively, Fig. 2 a shows the 20 interferograms calculated with respect to this master image and Fig. 2b shows the 46 interferograms computed for the SB approach. We limit our study area to the $40 \times 40 \mathrm{~km}^{2}$ surrounding the urban region (Fig. 1). For removing the topographic contribution from the interferograms, the global digital elevation model (GDEM) issued from the Advanced Spaceborne Thermal Emission and Reflection Radiometer (ASTER) version 2 with a resolution of $1.5 \mathrm{arcsec}$ has been used to obtain an external elevation of this area of interest. Otherwise, the contribution of flat earth was also removed by using precise orbit data accurate to $<1 \mathrm{~m}$, which are delivered with the level 1.0 product in the header file as 28 state vectors from JAXA.

\section{Results}

\subsection{Spatial distribution of subsidence}

A large number of SP $(540000)$ have been found within the region under study (Fig. 3). Most of these scatterers correspond to private houses, buildings and infrastructures, located within the dense settlements in urban districts and the surrounding villages in suburban districts. The places where no SP are selected correspond to water bodies or agricultural areas of rice fields surrounding the urban area. Assuming that most of the measured deformation corresponds to vertical displacement of the surface due to the subsidence, we convert the velocity obtained along the satellite line of sight into vertical velocity using the incident angle $(\theta)$ at each measurement point (average of $\theta=38^{\circ}$ for ALOS PALSAR images).

We observe a heterogeneous field of vertical velocity in the Hanoi urban region, with the vertical subsidence rate ranging from 0 to $68.0 \mathrm{~mm} \mathrm{yr}^{-1}$ over the 4 years under study (Fig. 3). First, we note that the deformation is mainly confined within the urban region. The mean vertical velocity field indicates a clear distinction between the northern and southern parts of the Red River. In the northern part, the ground surface appears to be very stable, with few small subsiding spots identifiable in the east of Dong Anh suburban district and between the Red River and the Duong River, such as near the headquarters of Long Bien urban district or in the southwestern part of Gia Lam suburban district (Fig. 3). For these local spots, whose horizontal extension does not
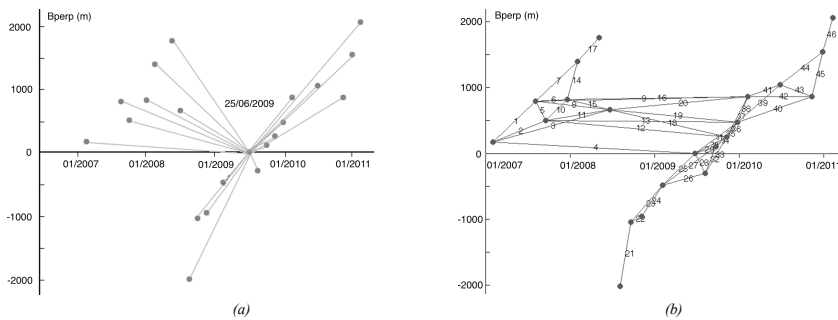

Fig. 2. Baseline plots for (a) the PS approach and (b) the SB approach. Perpendicular baseline (Bperp) is calculated with respect to the master image (date: 25 June 2009) used in the PS approach.

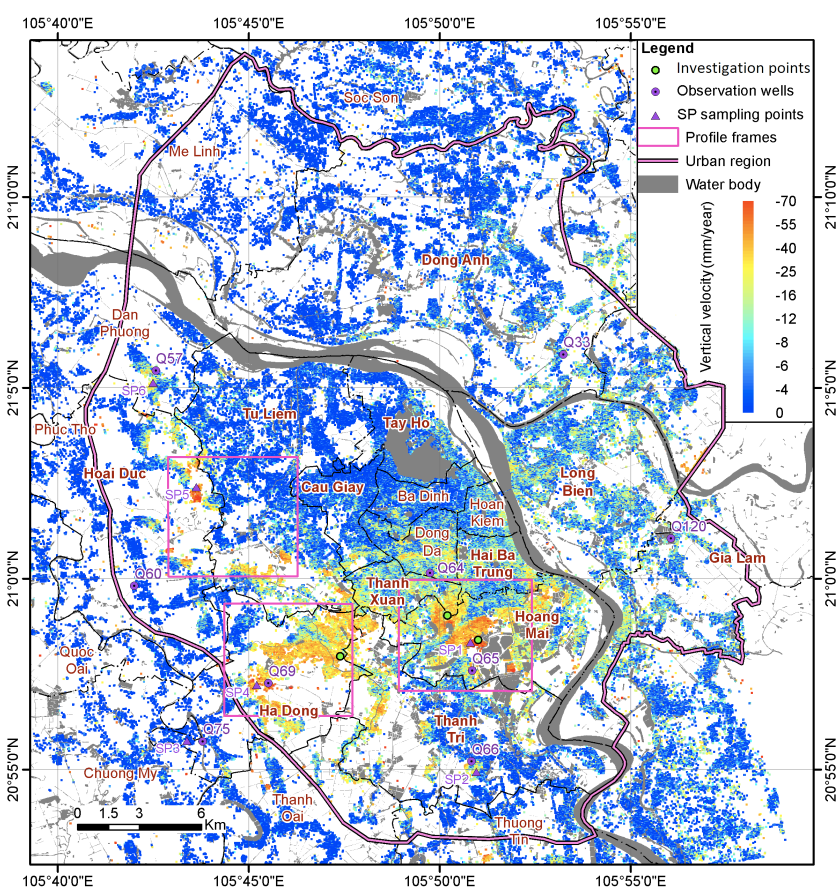

Fig. 3. Averaged vertical subsidence velocity in urban region of Hanoi (location in Fig. 1) issued from InSAR processing for the period February 2007-February 2011. Red boxes are the locations for Fig. 4a-c.

exceed $1-2 \mathrm{~km}^{2}$ each, the mean vertical velocity reaches a maximum of $15.0 \mathrm{~mm} \mathrm{yr}^{-1}$. The northern part of the southern bank, corresponding to the urban districts of Tay Ho, Ba Dinh, Cau Giay, and Tu Liem suburban district, is clearly distinguishable with very little deformation, except along the Red River, where a surface subsidence occurs at a slow rate, lower than $10.0 \mathrm{~mm} \mathrm{yr}^{-1}$.

In the southern bank, the land subsidence occurs in three main areas in the south and the west of the city (Fig. 3), which are similar to the analysis in the study of Vöge (2011). First, the largest area corresponds to the urban district of Hoang Mai, south of the city center. The deformation, corresponding to a mean subsidence rate larger than $30.0 \mathrm{~mm} \mathrm{yr}^{-1}$, covers a $5 \times 5 \mathrm{~km}^{2}$ surface, and is bounded 

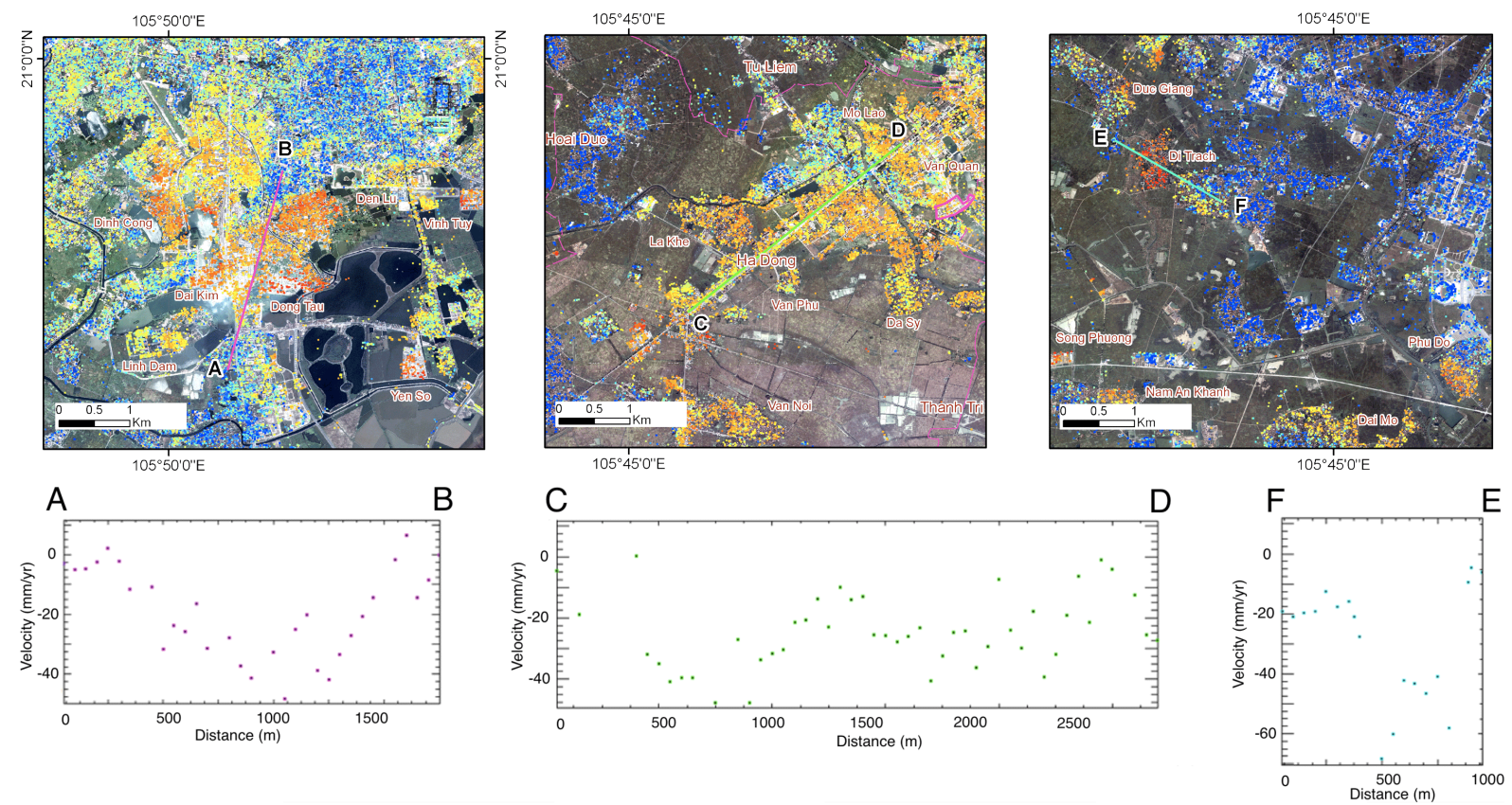

(a)

(b)

(c)

Fig. 4. Close-up maps and vertical velocity profile of (a) the Hoang Mai subsidence area, (b) the Ha Dong subsidence area (magenta boundary presents monitoring subsidence by leveling at Van Quan residential zone), and (c) the Hoai Duc subsidence area. For location of frame and color scale, refer to Fig. 3.

to the north by very sharp velocity gradients (Figs. 3 and 4a). The maximum mean vertical rate reaches $68.0 \mathrm{~mm} \mathrm{yr}^{-1}$, only $1 \mathrm{~km}$ away from a stable area. We note the particularly pointy shape of a very low deformation indenting into the main deformed area, and to the east of this first subsidence area, some patches of subsidence with a lateral extension not larger than $0.5 \times 0.5 \mathrm{~km}^{2}$ and a high vertical rate of $50.0 \mathrm{~mm} \mathrm{yr}^{-1}$. The second area of significant deformation is located in the Ha Dong-Thanh Xuan urban district in the southwest city center (Figs. 3 and 4b). The lateral extension of this second subsiding area is significant, up to $7 \times 4 \mathrm{~km}^{2}$ but very few places within this area exhibit a vertical rate higher than $45.0 \mathrm{~mm} \mathrm{yr}^{-1}$. We distinguish only a small site with a vertical rate of $60.0 \mathrm{~mm} \mathrm{yr}^{-1}$ in the south. To the west of the urban region, the third main area of deformation appears blurred due to the sparseness of scatterers in the suburban districts of Hoai Duc - Tu Liem, where the agricultural fields are still dominant (Figs. 3 and 4c). The patches draw a NW-SE elongated area of $18 \times 3 \mathrm{~km}^{2}$, in which the vertical velocity ranges from 30.0 to $60.0 \mathrm{~mm} \mathrm{yr}^{-1}$.

Located in the other parts of the urban region are several smaller patches of subsidence with a lateral extension smaller than $1 \mathrm{~km}^{2}$ such as Dong Da, Thanh Xuan or Hai Ba Trung with a vertical velocity ranging from 10.0 to $25.0 \mathrm{~mm} \mathrm{yr}^{-1}$, in other words, quite small in comparison to the three previously described areas (Fig. 3). These values are consistent with the results of Carnec and Raucoules (2001) for the 1996-1998 period.

\subsection{Temporal evolution analysis}

The time series decomposition has to be analyzed with caution since our period of observation covers only 4 years, with only 22 images used. Figure 5 presents the displacement over time for six specific pixels located within the three subsidence areas and near the selected instrumented wells (Fig. 3). For most them, we observe large variations in the evolution, which should be interpreted either as noise in the data due to inaccurate estimates of the baseline for instance, or an actual signal revealing a complex behavior of the ground and/or external processes responsible for this pattern. However, we note that the time evolutions of each of the selected pixels share the following characteristics. In the first half of the period under examination, the surface displacement shows a regular downward motion until the end of 2008. In the second half, the variations are larger in most of the graphs, with a succession of upward and downward ground motions. This difference between the two parts of our observation period suggests that the behavior of the aquifers dramatically changed at this moment.

In order to validate our results, we compare the values of the vertical subsidence rate for a specific area, for which other data are available. Sixteen leveling campaigns were carried out from 25 June 2007 to 26 September 2008 at several building blocks in Van Quan residential zone (located in second subsidence area in the Ha Dong-Thanh Xuan districts; location on Fig. 4b) by the Hanoi Housing and Urban 


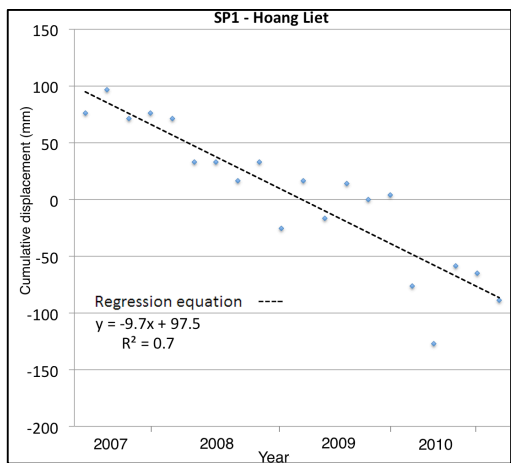

(a)

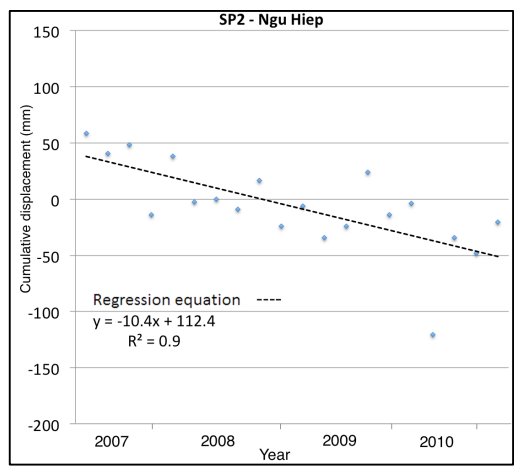

(b)

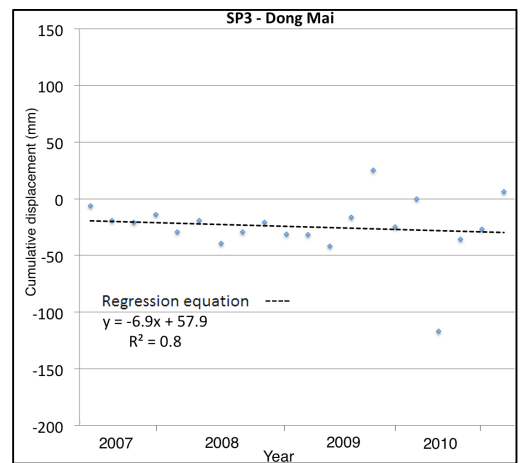

(c)

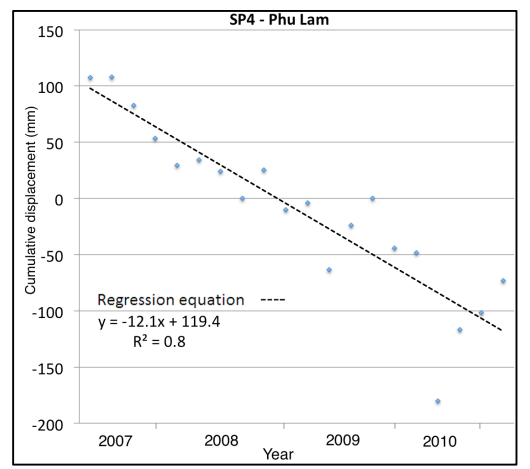

(d)

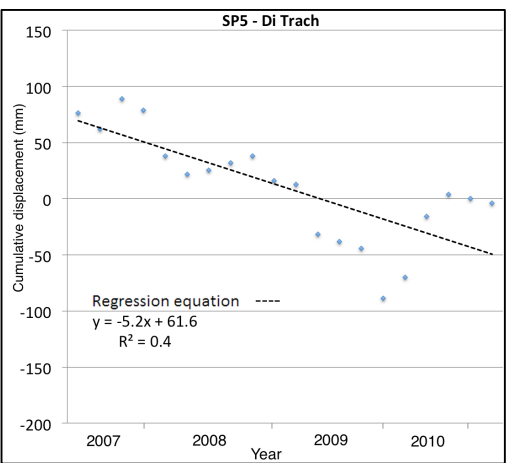

(e)

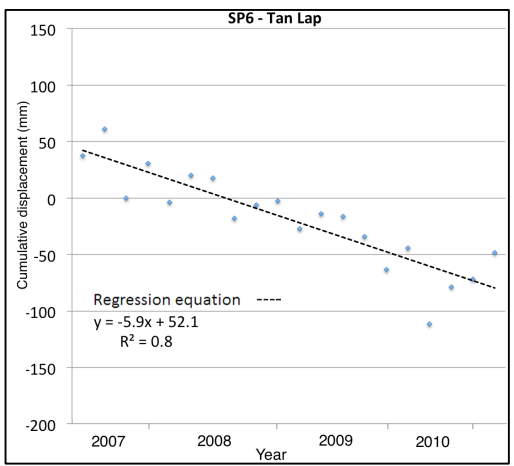

(f)

Fig. 5. Time series of vertical displacement at several SP pixels at (a) Hoang Liet, Hoang Mai, (b) Ngu Hiep, Thanh Tri, (c) Dong Mai, Ha Dong (d) Phu Lam, Ha Dong, (e) Di Trach, Hoai Duc, (f) Tan Lap, Hoai Duc. For location of SP sampling points, refer to Fig. 4.

Development Corporation. Here we look more precisely at the leveling data of building blocks TT18A and TT18B (Fig. 6a). The mean subsidence rate deduced from the leveling data corresponds to a mean velocity of $35.0 \mathrm{~mm} \mathrm{yr}^{-1}$ for block TT18A and $27.8 \mathrm{~mm} \mathrm{yr}^{-1}$ for block TT18B, respectively (Fig. 6b). Notably, these mean values are in agreement with our InSAR results, giving a mean value of $33.2 \mathrm{~mm} \mathrm{yr}^{-1}$ and $25.6 \mathrm{~mm} \mathrm{yr}^{-1}$ for the SP points located at corresponding building blocks. Nevertheless, we note that these values are smaller than the mean velocity of $90.0 \mathrm{~mm}$ during a period of 17 months (from 02 February 2007 to 22 June 2008) corresponding to $63.5 \mathrm{~mm} \mathrm{yr}^{-1}$ determined by Vöge (2011).

However, as mentioned above, this latter study used only two images processed by the DInSAR method, with all the related uncertainties due to atmospheric heterogeneities, time decorrelation, etc. We then look at the time evolution of these measurement points and observe a great similarity between the InSAR data and the leveling data over the period from June 2007 to September 2008, which is crucial for validating our InSAR results (Fig. 6c). During the same period, neither of these data sets follow a linear function, consistent with a constant velocity, but do describe a polynomial function of second degree. This suggests a slow decrease of the vertical velocity with time, which reveals a specific mechanical behavior of the layer submitted to a decrease of its pore pres- sure due to the water withdrawal. Therefore, unless there was significant noise included only in the data for the period after September 2008, the subsiding signal over Hanoi is clearly not stationary, but includes transient displacements.

\section{Discussion}

\subsection{Subsidence in relation with Quaternary geology}

Shallow geology is an important contributing factor to land subsidence phenomena and the spatial variations of its amplitude. In the north bank of the Red and Duong rivers, the dominant layers exposed at the surface at Dong Anh and Soc Son suburban districts correspond to clay and gravel of the Vinh Phuc formation, with porosity varying from 43 to $47 \%$ and low porous bedrock of middle Triassic $\left(T_{2}\right)$ is $-10.0 \mathrm{~m}$ below sea level (b.s.l.), at a maximum depth of $20.0 \mathrm{~m}$ below the topographic surface (Nguyen, 2005). In addition, the two pumping stations extract water at low rates. There are two explanations for the very low deformation observed in this part of Hanoi City. In the northern part of the south bank, even though the extraction rate of groundwater is very high and many new residential zones are being developed, little deformation is observed at the urban districts of Tay Ho, Ba Dinh, Cau Giay, and the Tu Liem suburban districts, where 


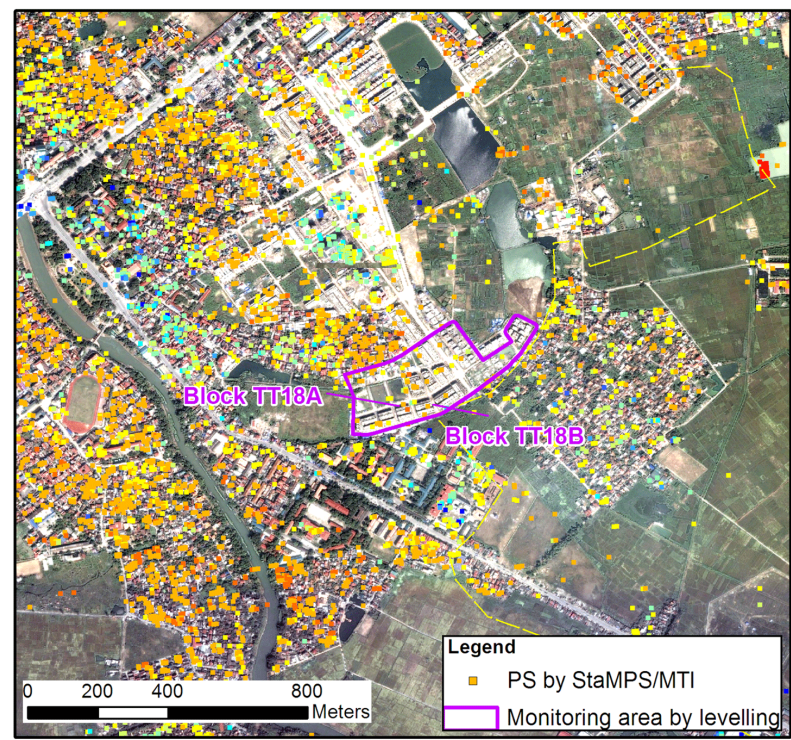

(a)

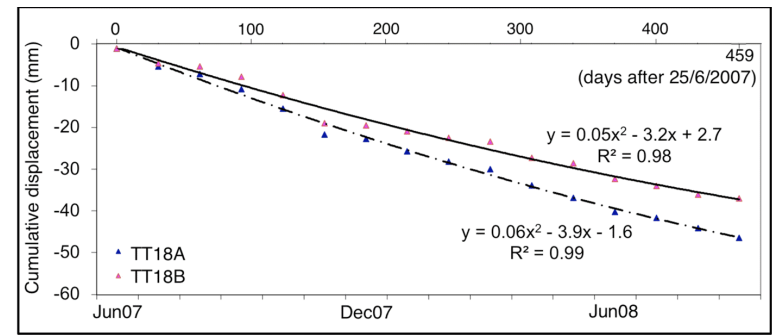

(b)

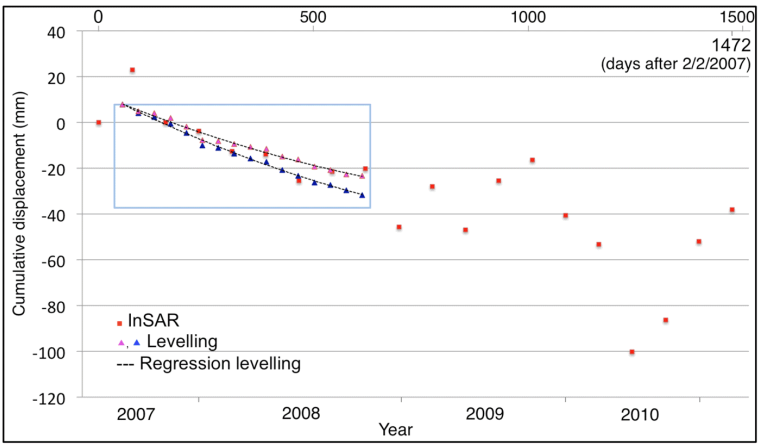

(c)

Fig. 6. (a) Monitored area by leveling in the Van Quan residential zone. For location of monitoring zone by leveling, refer to Fig. 4b, and for SP pixels in the area (color scale, refer to Fig. 3). (b) Leveling subsidence graph of blocks TT18A, TT18B (after Dinh et al., 2008). (c) Graphs of one SP located at blocks TT18A, TT18B and its leveling measurement. In order to adjust one set of data to the other one, we arbitrarily position the regression line of the leveling data through the third point of our InSAR time series.

geological layers are similarly composed by the deposits of the Vinh Phuc formation. However, south of the city center and between the two rivers, in the districts of Long Bien, Gia Lam, Hoang Mai, Thanh Tri, Thanh Xuan, Ha Dong, and Hoai Duc, the sedimentary layers below the marshy surface consist of Holocene deposits of the Hai Hung and Thai Binh formations. The Hai Hung formation contains several layers of clay, sand with the porosity varying from 51 to $63 \%$; otherwise the Thai Binh formation contains gravels, sand and clay layers with an upward fining succession and the porosity varying from 45 to $61 \%$. These formations include some lens of plastic and soft materials with low bearing capacity (Nguyen, 2005). The deeper geological layers below the three largest subsidence areas of Hoang Mai, Ha DongThanh Xuan, and Hoai Duc-Tu Liem districts correspond to soft soil containing organic matters, sand, sandy clay, loamy sand or clay loam (Figs. 7a and 8a). The groundwater level in $Q_{\mathrm{h}}$ aquifer is located at a maximum depth of $-6.0 \mathrm{~m}$ b.s.l. (11.5 $\mathrm{m}$ below the topographic surface) due to the withdrawal of main well fields (Fig. 7a).

\subsection{Subsidence in relation to human activities}

In terms of resource and environmental perspectives, the most apparent consequence of urbanization is the various changes in the hydrologic cycle (Mays, 2009), which are considerably perturbed by the modification of soil properties
(Haase, 2009). As human spaces become increasingly dominant through the urbanization process, impermeable materials such as concretes, plastics or asphalts increasingly replace natural surfaces. The impermeable coverage induces a reduction of the amount of evapotranspiration, to increase the runoff and to prevent the infiltration and the recharge of groundwater beneath the city surface. In addition, the rapid growth of human population and industry has put a great pressure on water demands for domestic and commercial purposes. Therefore, the extensive housing construction and groundwater extraction that causes significant static and dynamic loads are expected to be land subsidence triggers, particularly in an area where unconsolidated sediments in the Red River plain are characterized by high porosity.

\subsubsection{Urban sprawl}

After the removal of a government subsidized housing system at the end of the 1980s, an explosion of housing construction occurred in the city center in order to accommodate a rising urban population. At its initial stage, private house construction began with a principle of densification within the limit of Ba Dinh, Hoan Kiem, Dong Da, and Hai Ba Trung central districts (Fig. 10a; before 1993). Then, the urban landscape changed to reflect added urban sprawl, which took place mainly along the major national roads in Thanh Tri suburban district in the south, Tu Liem suburban district 


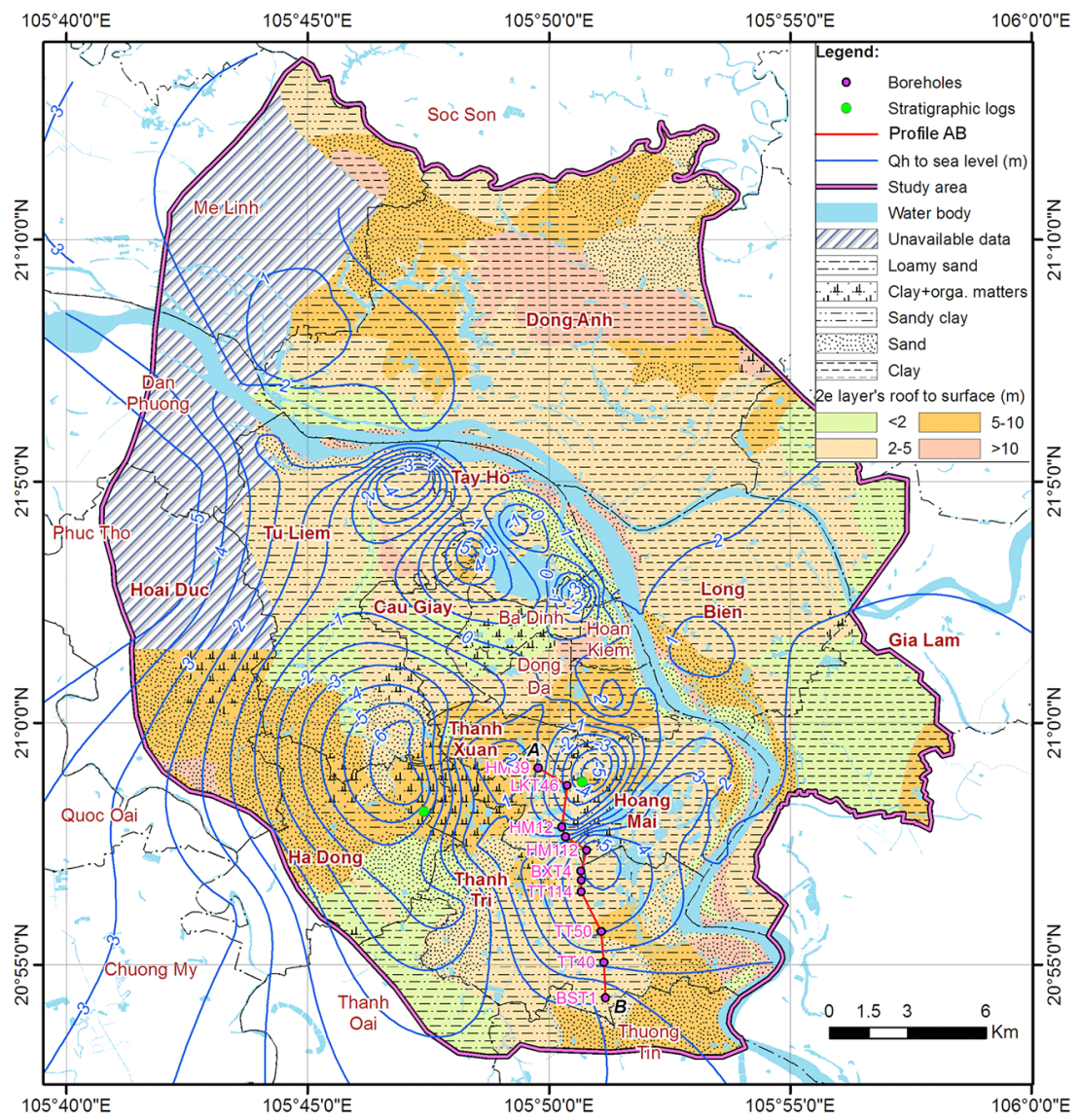

(a)

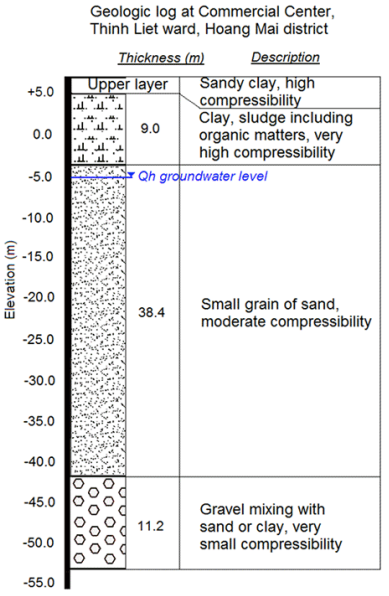

(b)

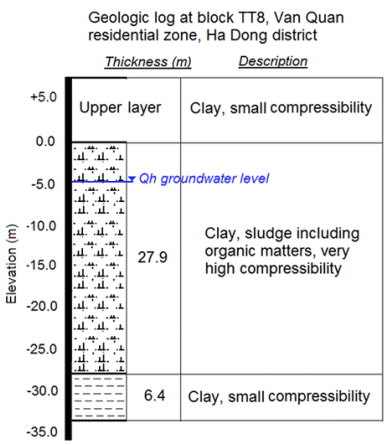

(c)

Fig. 7. (a) Geological map of second layer, (after Nguyen, 1996a) and averaged groundwater level in $Q_{\mathrm{h}}$ aquifer interpolated from in situ measurements in 32 wells (after Vietnam Institute of Geosciences and Mineral Resources, 2010). Stratigraphic logs at (b) Hoang Mai district, (c) Ha Dong district (after Nguyen, 2009).

in the west, Thanh Xuan urban district in the southwest and Long Bien urban district in the northeast. Then the urban development spread to the western, southwestern and the northern parts of city center with the creation of Tay Ho district in 1995, and Cau Giay, and Thanh Xuan urban districts in 1996 (Fig. 10a, between 1993 and 2000). Although the housing crisis in the urban districts was gradually softened by private constructions, most of those developments were realized without permission from the master plan.

At the end of 1990s, a planning measure was applied with a new concept of residential zoning, in which urban infrastructures for green space, drinkable water, electricity, and roads were developed simultaneously with the housing accommodations. Typically each new residential zone now contains several buildings of over 20-30 floors, an area for private individual houses with several floors and an area for adjacent condominiums with four or five floors. Over the last decade, the housing construction has consisted of the deployment of more than 100 new residential zones by public construction or foreign joint venture companies, whose surfaces range from small projects (several hectares) in the urban dis- tricts to big projects (up to several hundred hectares) in its periphery (Labbé, 2010) and the built-up surfaces have been steadily increasing, except in 2007, when the global financial crisis occurred (Fig. 10b). With the creation of Long Bien and Hoang Mai urban districts in 2003, the built-up surfaces have continued to spread to the west of the city center in the urban district of Cau Giay, to the northwest in the Tay Ho urban district, and to the southeast in the Hoang Mai urban district, where the first subsidence area has risen in a densely constructed region encompassing many new residential zones and small houses. In this subsidence area, the highest mean velocity corresponds to the constructions in Dong Tau, Dai Kim, Yen So, Dinh Cong, Linh Dam, Den Lu new residential zones and Vinh Tuy industrial park (Fig. 4a). The urban expansion is still limited in the north bank of the Red River and in the southern part of the city center due to natural barriers such as streams or wetland areas (Fig. 10a, between 2000 and 2007). 


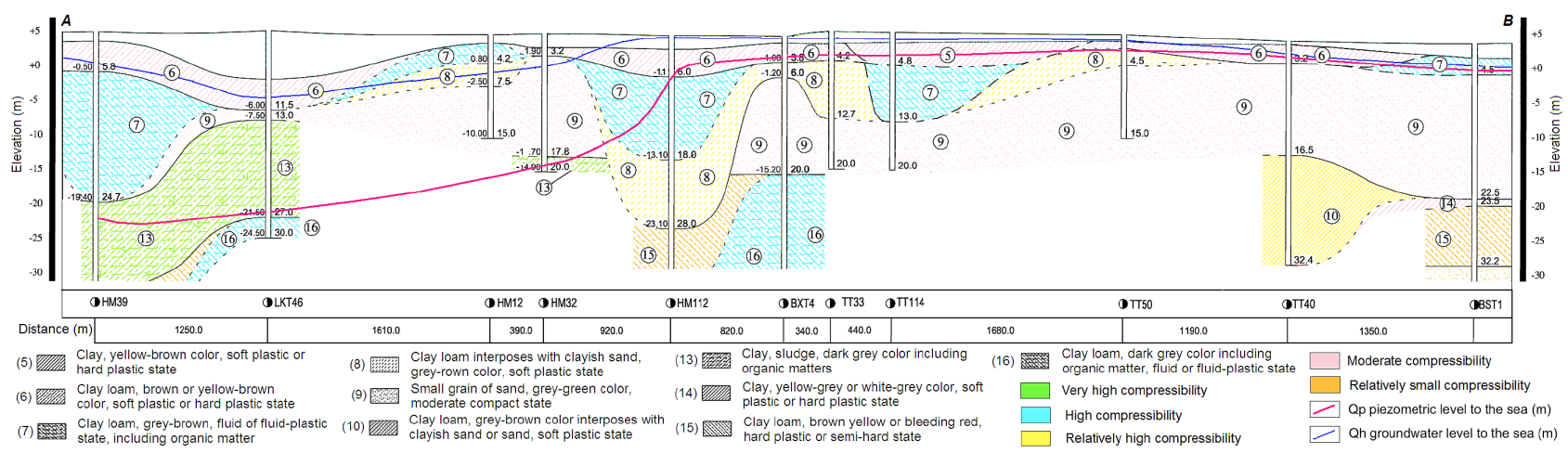

(a)

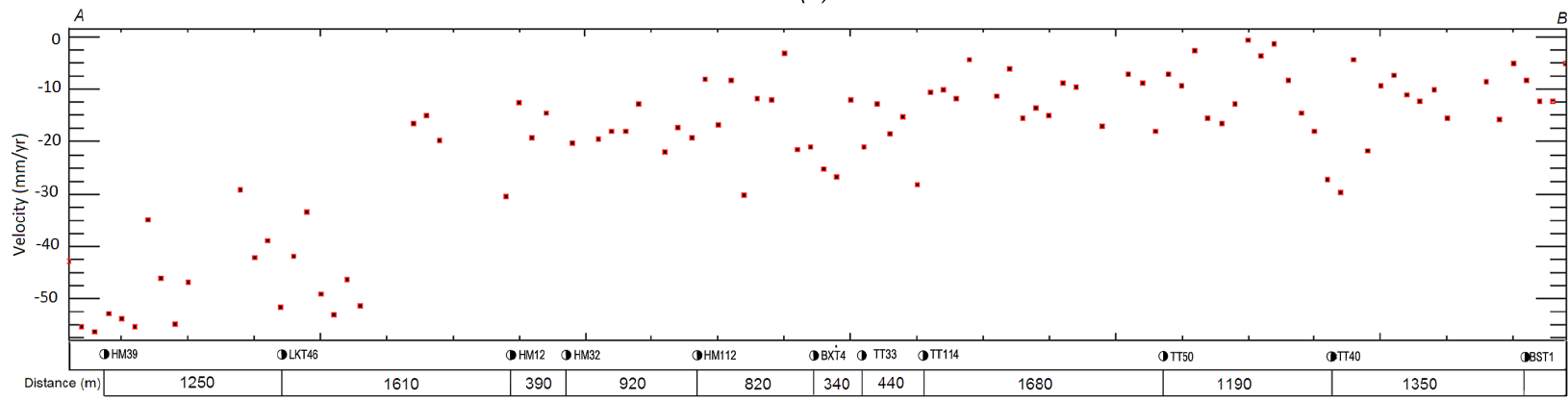

(b)

Fig. 8. (a) Geologic profile $\mathrm{AB}$ of first subsidence area, (modified from Nguyen, 2005), groundwater level in $Q_{\mathrm{h}}$ aquifer (blue), (after Vietnam Institute of Geosciences and Mineral Resources, 2010), and piezometric level of $Q_{\mathrm{p}}$ aquifer (red), (after the Northern Division of Planning and Investigation for Water Resources, 2010). For spatial pattern of isocontours, refer to Fig. 11. (b) Graph of InSAR vertical velocity following the profiles AB. For location of profile AB, refer to Fig. 7 or Fig. 11.
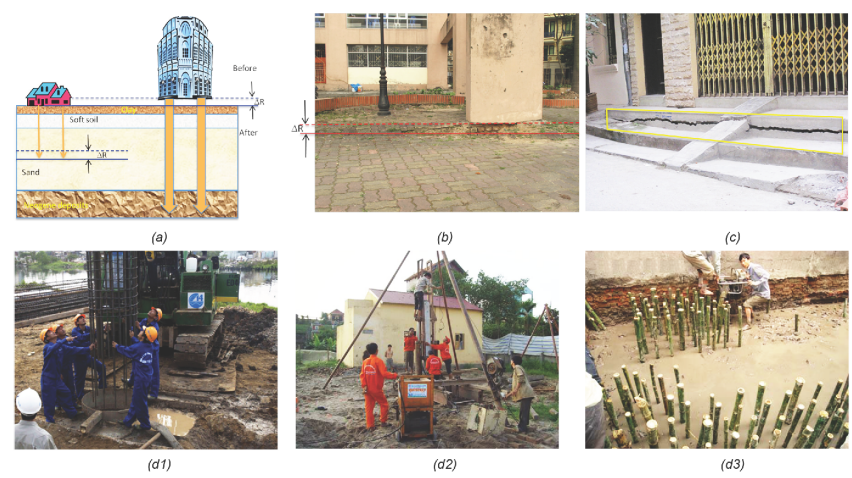

Fig. 9. (a) Model of subsidence process. Example of subsidence damages in (b) Dinh Cong residential zone at Hoang Mai subsidence area. (c) Van Quan residential zone at Ha Dong subsidence area. For location of investigation points, refer to Fig. 3. Several types of foundation are used in the study area: (d1) augercast piles, (d2) concrete pillars, (d3) bamboo piles (after: http: //www.cocbetong.vn).

Until the administrative regulation event in May 2008, 772 new residential and industrial projects have been planned in the new Hanoi City region, occupying $145.7 \times 10^{3}$ ha, 25000 ha of which are located in the former boundary (VET, 2008) and many big projects have been deployed all around the urban region. The isolation of the northeastern territory was removed with the new bridges crossing over the Red River, and new residential zones were set up at eastern Long Bien and Gia Lam districts, explaining the appearance of small discrete subsidence spots between the south bank of Duong River and the north bank of the Red River. The developed surfaces are expanding to the main directions of previous periods, but are very strong in the west and southwest suburban districts such as Hoai Duc, Phuc Tho, Tu Liem and Ha Dong urban district, where the second and third subsidence areas are located, corresponding to the implementation of big residential zones such as Van Quan, Van Phu, Mo Lao, Nam An Khanh. This includes the private house construction in traditional villages such as La Khe, Da Sy, Van Noi, Phu Do, Dai Mo, Song Phuong, and Di Trach (Fig. 4b, c). This process helped to connect surrounding villages to developed urban spaces. However, the discrete connection of the recently urbanized villages in Hoai Duc and Tu Liem suburban districts corresponds to the small patches of the third main subsidence area (Fig. 10a, between 2007 and 2011).

Thus, the three main subsidence areas are located in the new urban districts created after 2003 and their suburban neighborhoods, in which many new residential zones have been developed and traditional villages have been transformed over the last decade. The variation of the SP pattern 


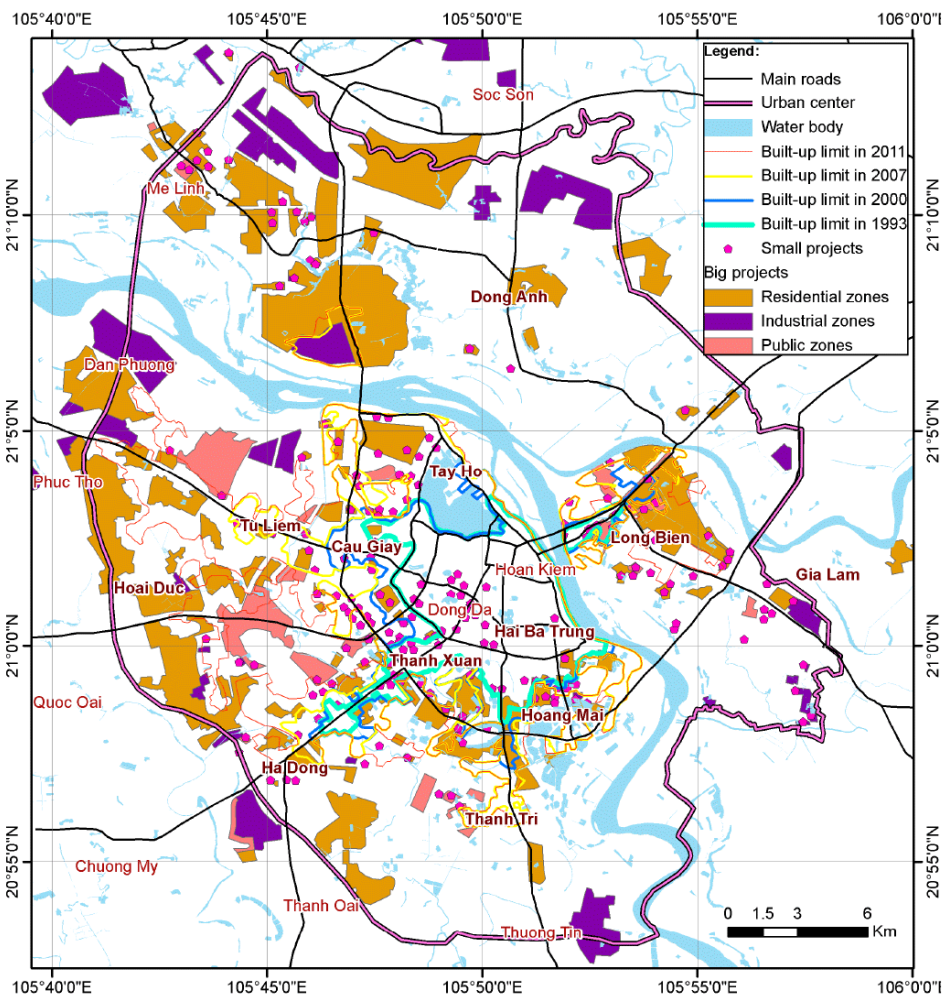

(a)

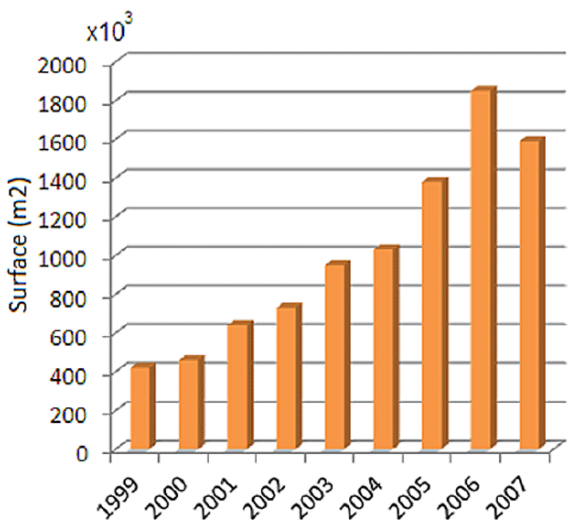

(b)

Fig. 10. (a) Location of new construction projects by public construction companies in urban region of Hanoi City, (after NARENCA, 2010) and evolution of built-up surfaces until 1993, 2000, 2007, and 2011 digitized from Landsat images. (b) Evolution of Hanoi housing surfaces constructed $\left(\times 10^{3} \mathrm{~m}^{2}\right)$ from 1999 to 2007, (after Hanoi Department of Construction, 2009).

shows a relation between the subsidence with the density of built-up surfaces, which ranges from the dense construction (urbanized areas) such as the first subsidence area in Hoang Mai urban district, to the moderate construction (urbanizing area) such as the second subsidence area in Ha Dong-Thanh Xuan urban districts, and to sparse construction (urbanizing villages) such as the third subsidence area in Hoai Duc - Tu Liem suburban districts.

\subsubsection{Groundwater extraction}

The groundwater supply in Hanoi City has evolved in urban districts since the 19th century, in particular in the recent period, with the increase of population density and the economic changes. Two types of groundwater extraction management currently exist for industrial production and drinking water. First, the centralized extraction is managed by the Hanoi Water Supply Company (Hawaco) with 11 well fields and 7 small stations accounting for a total of 200 wells, which allow for the extraction of the groundwater from the Pleistocene aquifer $\left(Q_{\mathrm{p}}\right)$. The average withdrawal from these well fields has been monitored, showing continuous rising of groundwater extraction over the last decades for domestic and industrial demand and for public services in urban districts. The inventories or research results of Nguyen and
Helm (1995), Tong et al. (2001), Duong et al. (2003), and Montangero et al. (2007) propose the following evolution of the $Q_{\mathrm{p}}$ extraction: $86.5 \times 10^{3} \mathrm{~m}^{3} \mathrm{day}^{-1}$ in the period of $1955-1965,180 \times 10^{3} \mathrm{~m}^{3} \mathrm{day}^{-1}$ in the period of 1975-1985, $400 \times 10^{3} \mathrm{~m}^{3}$ day $^{-1}$ in $2001,450 \times 10^{3} \mathrm{~m}^{3}$ day $^{-1}$ in 2003 , and eventually up to $620 \times 10^{3} \mathrm{~m}^{3} \mathrm{day}^{-1}$ in 2007 . Second, a decentralized extraction has been made by many factories or companies, which drilled from their own wells due to the inability of Hawaco's system to assure their proper industrial functioning. They directly extract groundwater from the confined Pleistocene aquifer $\left(Q_{\mathrm{p}}\right)$ and the rate of extraction was estimated to be $120 \times 10^{3} \mathrm{~m}^{3}$ day $^{-1}$ in 2000 (Tong et al., 2001). Moreover, households in suburban districts extract drinkable water using shallow drilling wells in the Holocene aquifer $\left(Q_{\mathrm{h}}\right)$, whose number and extraction amounts are impossible to estimate (Tong et al., 2001).

Almost all the centralized water production plants are concentrated in the urban districts of the southern bank of the Red River, where population density is the highest (Fig. 11). The two largest subsidence areas in Hoang Mai and Ha Dong-Thanh Xuan urban districts are located close to the groundwater well fields, which have a capacity of exploitation varying from $16 \times 10^{3}$ to $35 \times 10^{3} \mathrm{~m}^{3}$ day $^{-1}$ (PPJ et al., 2011). The first main vertical deformation area identified in 


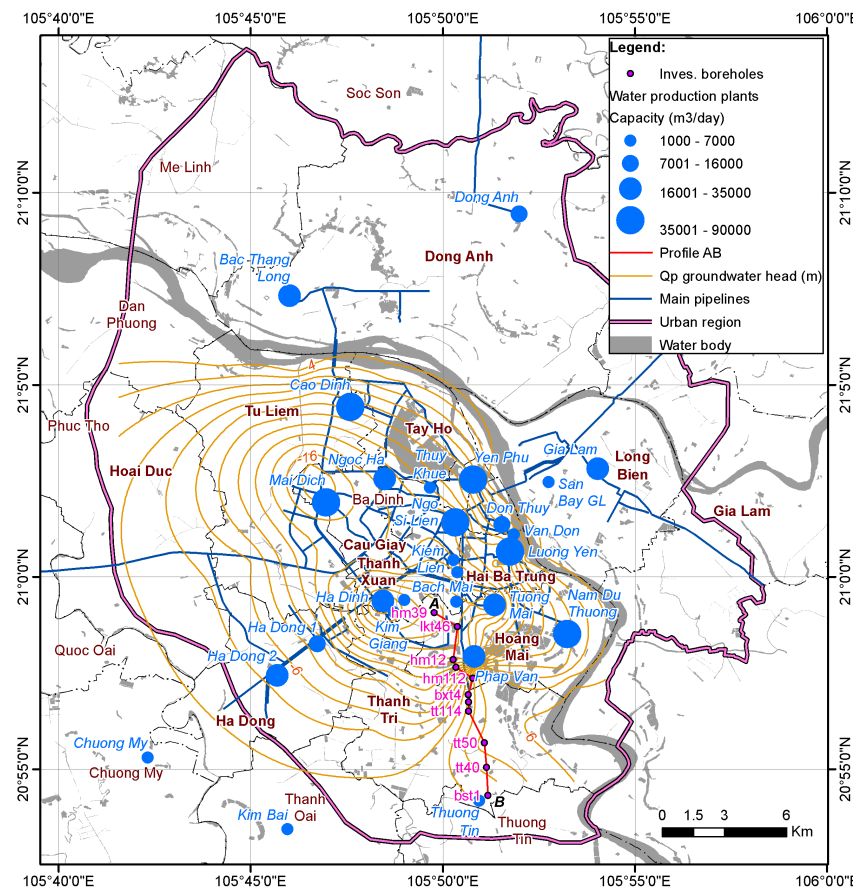

Fig. 11. Isocontours of the averaged groundwater piezometric level (to sea level) in $Q_{\mathrm{p}}$ aquifer of Red River's southern part interpolated from in situ measurements in 21 wells during 2006 (after the Northern Division of Planning and Investigation for Water Resources, 2010) and withdrawal capacity of Hawaco water production plants, (after Hanoi Department of Planning and Architect, 2011).

Hoang Mai urban district is located between the two large Phap Van and Tuong Mai well fields, where the groundwater withdrawal reaches $24 \times 10^{3} \mathrm{~m}^{3}$ day $^{-1}$ each. We note that the groundwater piezometric head level in $Q_{\mathrm{p}}$ aquifer is deep, down to $-17.0 \mathrm{~m}$ b.s.l. in 2010 (Fig. 11). The second main vertical deformation area is located between three well fields in the Thanh Xuan and Ha Dong urban districts (Ha Dinh, Ha Dong 1 and Ha Dong 2) with a withdrawal capacity reaching $23 \times 10^{3} \mathrm{~m}^{3}$ day $^{-1}$ per well field, and where the groundwater piezometric head levels in $Q_{\mathrm{p}}$ aquifer was located at -8.5 m b.s.l. in 2010 at observation well $Q_{69}$ (Fig. 12b). This value reached $-4.3 \mathrm{~m}$ b.s.l. in 2006 in the same area (Nguyen and Nguyen, 2007). The intensive groundwater withdrawal of $Q_{\mathrm{p}}$ aquifer from important well fields results not only in the drawdown of piezometric head in $Q_{\mathrm{p}}$ aquifer but also in the drawdown of the groundwater level in $Q_{\mathrm{h}}$ aquifer due to an interconnection between them in a multi-aquifer system (Alexander and Cheng, 2000). Moreover, the recorded data between 1995 and 2009 in selected monitoring wells show that the groundwater level in $Q_{\mathrm{h}}$ aquifer has decreased from 4.1 to $3.1 \mathrm{~m}$ a.s.l. at a rate of $-0.07 \mathrm{~m} \mathrm{yr}^{-1}$ at the south bank of the Red River (Bui et al., 2010). On the contrary, in the western and southern belt of the urban region, the third largest subsidence area is not associated with any large Hawaco well fields. In these areas, the drinkable water for households is extracted from $Q_{\mathrm{h}}$ aquifer through private shallow wells, and the development of many factories need their own water sources, whose the decentralized groundwater extraction amount from $Q_{\mathrm{p}}$ aquifer is impossible to estimate.

We compare our time series of the surface displacement with the evolution of the groundwater level in $Q_{\mathrm{h}}$ aquifer and piezometric level of $Q_{\mathrm{p}}$ aquifer measured by Hanoi Center for Water Resources Planning and Investigation during the period from 2006 to 2010 at seven selected instrumented wells (Fig. 12): $Q_{65}$ at Hoang Liet (Hoang Mai district), $Q_{69}$ at Phu Lam (Ha Dong district), $Q_{57}$ at Tan Lap in the north of Hoai Duc district, $Q_{66}$ at Ngu Hiep in the south of Thanh Tri district, $Q_{75}$ at Dong Mai (Ha Dong district), $Q_{120}$ at Trau Quy (Gia Lam district), $Q_{60}$ at An Thuong (Hoai Duc district).

First, in order to understand the temporal evolution of these latter water levels, we look at the evolution of rainfall during the same period. We note that, for most of the wells, the variation of groundwater in aquifers follows the variations of rainfalls with clear seasonal fluctuations: rainy season (from May to September) or dry season (from October to April). We note particularly that the extreme rainfall on 31 October 2008 with more than $350 \mathrm{~mm}$ also appears in these water level time series, which indicates the water infiltration phenomenon (Fig. 12a). The correlation between the rain and the water levels in aquifers is especially clear in rural areas, where permeable surfaces are dominant and allow the natural recharge of these aquifers (Fig. 12f-h). Above the three wells with $Q_{120}, Q_{75}$ and $Q_{60}$, very low deformation affects the ground surface with the largest vertical velocity of $12 \mathrm{~mm} \mathrm{yr}^{-1}$ in the vicinity of well $Q_{120}$ (Fig. 3). In the newly urbanized villages such as the northern part of Hoai Duc district and the southern part of Thanh Tri district, the time evolution of the groundwater level of $Q_{\mathrm{h}}$ aquifer shows clear seasonal variations in the $Q_{57}$ and $Q_{66}$ wells (Fig. 12d, e). However, the piezometric level in $Q_{\mathrm{p}}$ aquifer is located $5.0 \mathrm{~m}$ deeper than the groundwater level in $Q_{\mathrm{h}}$ aquifer, changing by seasonal pattern to a linear decrease with a rate of $1.0 \mathrm{~m} \mathrm{yr}^{-1}$ starting from 2009. These areas are affected by the subsidence, with a small rate ranging from 16.0 to $25.0 \mathrm{~mm} \mathrm{yr}^{-1}$ (Fig. 3). Regarding the urbanizing Ha Dong district, where our InSAR results show a vertical rate of the ground deformation ranging from 45.0 to $60.0 \mathrm{~mm} \mathrm{yr}^{-1}$ (Fig. 3), the evolution of groundwater levels in both aquifers at $Q_{69}$ well, located nearby the Ha Dong 2 production water plant (Fig. 11), does not show any seasonal variations. The water levels show a continuous lowering from 2006 at a mean rate of $1.0 \mathrm{~m} \mathrm{yr}^{-1}$ and $0.7 \mathrm{~m} \mathrm{yr}^{-1}$ for $Q_{\mathrm{p}}$ and $Q_{\mathrm{h}}$, respectively. However, it is important to note a clear acceleration of the water lowering from 2009 (Fig. 12b). In the urbanized Hoang Mai district, well $Q_{65}$ is located in the margin of the largest subsiding area with a subsidence rate varying from 20.0 to $42.0 \mathrm{~mm} \mathrm{yr}^{-1}$ (Fig. 3). The evolution of the water level in the $Q_{\mathrm{h}}$ aquifer remains constant over time, when the piezometric level in 


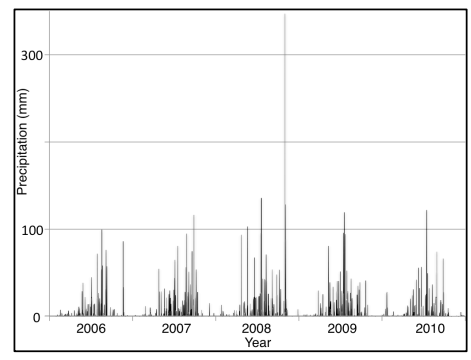

(a)

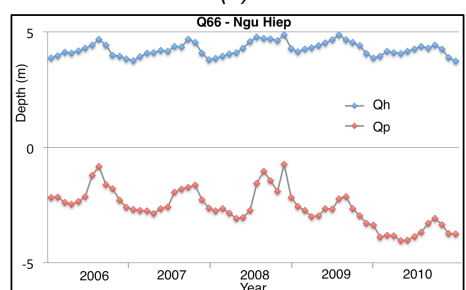

(e)

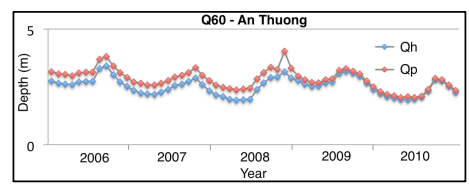

(h)

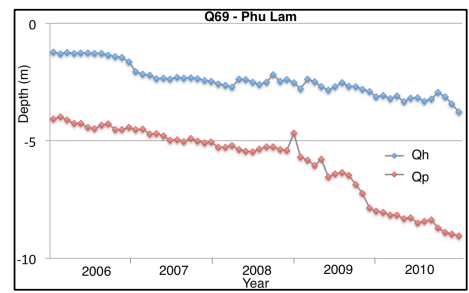

(b)

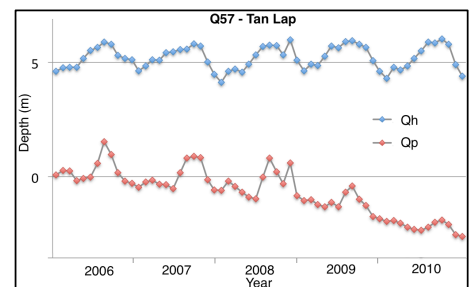

(d)

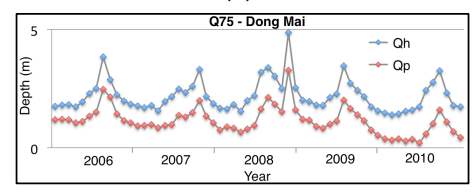

(g)

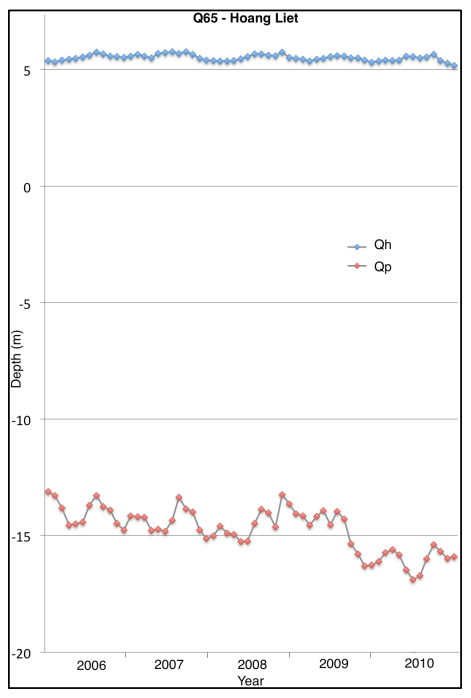

(c)

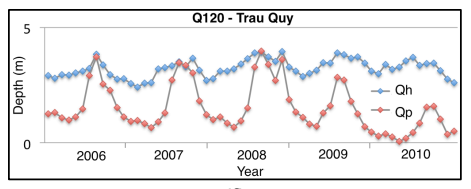

(f)

Fig. 12. (a) Precipitation at Lang meteorological station from 2007 to 2010, (after National Hydro-Meteorological Service, 2011). Average groundwater and piezometric level in $Q_{\mathrm{h}}, Q_{\mathrm{p}}$ during the 2006-2010 period at (b) $Q_{69}$ at Phu Lam, Ha Dong, (c) $Q_{65}$ Hoang Liet, Hoang Mai, (d) $Q_{57}$ at Tan Lap, Hoai Duc, (e) $Q_{66}$ Ngu Hiep, Thanh Tri, (f) $Q_{120}$ at Trau Quy, Gia Lam, (g) $Q_{75}$ at Dong Mai, Ha Dong, (h) $Q_{60}$ at An Thuong, Hoai Duc, (after Nguyen and Nguyen, 2007, 2008; Nguyen and Pham, 2009, 2010; Nguyen et al., 2011). For location, refer to Fig. 3.

$Q_{\mathrm{p}}$ aquifer exhibits a complex time evolution with variations (Fig. 12c), but not as clear as for the wells $Q_{75}, Q_{120}, Q_{60}$.

The evolution of water levels in all observation wells clearly shows the acceleration of groundwater withdrawal in $Q_{\mathrm{p}}$ aquifer, especially after the Hanoi's administrative regulation in May 2008 with the rising demands for water. The comparison of InSAR data with the data of water level in the aquifers suggests the important effect of the intense urbanization on the water resources. The development of impermeable coverage prevents the infiltration of precipitation for the recharging of $Q_{\mathrm{h}}$ aquifer, together with the drawdown of piezometric level in $Q_{\mathrm{p}}$ aquifer due to pumping; this level of $Q_{\mathrm{h}}$ aquifer could be also lowered in the adjacent areas of water production plants.

\subsection{Combination of multiple factors}

We therefore suggest that the spatial variations of the subsidence observed from our InSAR results over the Hanoi urban region are related to a combination of the lateral variations of several factors such as: the geological composition of the underground, the piezometric level in the $Q_{\mathrm{p}}$ aquifer, the density of urban development, and the foundation design of the constructions. The first subsidence area in Hoang Mai district is a good example of this combination, which explains the variations of the mean velocity from the northern to the southern parts of this area (Fig. 4a). In the north, the first meters of the ground correspond to sandy clay with organic matter and sand layers, that is, material susceptible to compaction due to a loading weight and a reduction of water content in the pore medium (Figs. 7b and 8a). In this area, Phap Van and Tuong Mai water production plants operate with an important withdrawal capacity (Fig. 11). At the northern part of the subsidence area, the density of construction is very high. The groundwater level in the $Q_{\mathrm{h}}$ aquifer is down to $-5.0 \mathrm{~m}$ b.s.l., which corresponds to a depth of $10.0 \mathrm{~m}$ below the topographic surface. The piezometric level in the $Q_{\mathrm{p}}$ aquifer is down to $-17.0 \mathrm{~m}$ b.s.l., which corresponds to a depth of $22.0 \mathrm{~m}$ below the topographic surface (Fig. 12c). The maximum of deformation is located precisely where the water level in the $Q_{\mathrm{p}}$ aquifer is deeper (Fig. 8a, b). North of the location of maximum deformation, the presence of sharp gradients of deformation could be explained by the abrupt variation of thickness of sand and clay loam layers surrounding borehole LKT46 (Figs. 7a and 8a). In the southern part of this subsidence area, in Thanh Tri and Thuong Tin suburban districts, the subsidence rates are very low (Fig. 8b) even if the geology is similarly loamy sand and sand layers (Figs. 3 and 7a). However, below these districts the groundwater level 
in $Q_{\mathrm{h}}$ aquifer remains high, up to $4.5 \mathrm{~m}$ above sea level (a.s.l.) and the piezometric level in $Q_{\mathrm{p}}$ aquifer remains high, up to $-0.5 \mathrm{~m}$ b.s.l. (Fig. 8a); no water production plants are susceptible to affect the water level in the deep $Q_{\mathrm{p}}$ aquifer.

The subsidence affecting the second subsidence area at Ha Dong and Thanh Xuan urban districts, where the density of construction is moderate, seems to result from a similar combination of effects. The groundwater level in $Q_{\mathrm{h}}$ aquifer dropped to $-6.0 \mathrm{mb}$.s.l. ( $11.5 \mathrm{~m}$ below the topographic surface), the piezometric level in $Q_{\mathrm{p}}$ aquifer has dropped to $-9.0 \mathrm{~m}$ b.s.l. ( $14.5 \mathrm{~m}$ below the topographic surface) (Fig. 12b), and at a deeper level, the well fields of $\mathrm{Ha}$ Dinh, Ha Dong 1 and Ha Dong 2 water production plants operate with an important withdrawal capacity (Fig. 11). The soft soil layers mixed with organic materials present at the boundary of two districts (with a thickness reaching $28.0 \mathrm{~m}$ ), which create a difficulty to impale the piles through this thick layer during the foundation works (Fig. 7c). A large region of sand or sandy clay surrounding this soft soil layer south of Ha Dong district is also susceptible to the drawdown of the groundwater level (Fig. 7a). Even in the third subsidence area at Hoai Duc - Tu Liem suburban districts, where the density of construction is much lower, the surface deformation occurs with smaller amplitude than in the two previous areas. Note that the recent urbanization is starting to be associated with a drawdown of piezometric levels in $Q_{\mathrm{p}}$, which has dropped to $-3.0 \mathrm{~m}$ b.s.l. ( $10.0 \mathrm{~m}$ below the topographic surface) (Fig. 12d, e). However, it also represents a potential hazard, since soft soil with organic matter and sand, sandy clay or loamy sand of Hai Hung and Thai Binh formations are superficial and the installation of the many factories during last decades, and the development new residential areas is planned in the near future (Fig. 10a).

In all three subsidence areas, we observe very little damage to the structures of tall buildings. We propose that these buildings (that form most of the SP) are not affected by subsidence because their steady foundations are based on auger-cast piles, reaching the Neogene deposits at a depth of 50.0 to $70.0 \mathrm{~m}$ (Fig. 9a, d1). The 20 leveling measurements for the CT2 building at Van Khe (Ha Dong) from October 2008 to September 2010 show a total value of $-22.3 \mathrm{~mm}$ for vertical subsidence, corresponding to an average of $-0.97 \mathrm{~mm} \mathrm{month}^{-1}$ (Diem et al., 2010). However, their surrounding terrain is collapsing (Fig. 9b, c), and many private houses nearby that use pile foundation methods with concrete pillars (Fig. 9d2) or bamboo piles (Fig. 9d3) are subsiding.

The choice of foundation types could be explained as follows: first, if the pile foundation is rooted into the thick soft soil layers with low load-bearing capacity, the houses are naturally sunk due to the compaction effect under the impact of a heavy load (Fig. 7c). Second, the concrete pillars could be impaled through the few meters of thick soft soil and reach deeper into a level of sand or loamy sand with moderate bearing capacity (Nguyen, 1996b) (Fig. 7b). The pillars could have been stable initially; the drawdown of the piezometric level of $Q_{\mathrm{p}}$-confined aquifer due to pumping activities could lead to a lowering of groundwater level in the $Q_{\mathrm{h}}$ aquifer, which will make the higher part of the clay mixing organic matters layer or sandy clay layer in this non-confined aquifer becoming regularly non-submerged into groundwater. This reduces the pore pressure in such geologic layers with high porosity to induce the compaction (Morris et al., 2003). Consequently, the pillars become unstable and the constructions are affected by subsidence (Downing, 1994). Third, many private houses are based on foundations consisting of bamboo piles and an insidious problem is the drying out of the bamboo piles. As long as bamboo piles remain saturated by groundwater, they resist rot and can last for centuries. However, if the $Q_{\mathrm{h}}$ water table drops below the pile tops, bamboo rot is rapid and building supports may collapse within a few years (Shanahan, 2009). Fourth, the intensive withdrawal of the $Q_{\mathrm{p}}$ aquifer generates the groundwater flows in shallow subsurface medium composed of sand and loamy sand layer to form a problem known as "loss of fines". This internal process facilitates the removal of sand particles, and erosion channels are promoted in the subsurface, inducing a collapse of the ground surface (Cashman and Preene, 2002).

\section{Conclusions}

Over the past 5 years, Hanoi City has undergone an extensive urbanization process and many construction projects are planned for the near future. The urbanization will trigger urban sprawl as well as the infrastructure networks expanding the urban districts around the Hanoi region. Adequate methods for monitoring geo-hazards in the new urban region are crucial for the city authorities to survey the subsidence phenomenon and limit its damaging consequences. Using interferometric radar technique, we investigate the scope of ground deformation related to the subsidence from 2007 to 2011. The StaMPS/MTI approach provides complete spatial coverage of the area under study, and together with the use of new L-band ALOS-PALSAR images, allows us to overcome the decorrelation problem in tropical regions such as Hanoi. Therefore, for the first time, a map of the mean subsidence velocity over the urban region of Hanoi City has been obtained. This map shows that the mean vertical subsidence rate ranges from 0 to $68.0 \mathrm{~mm} \mathrm{yr}^{-1}$, and the larger zones of deformation correspond to the three main areas in Hoang Mai, Ha Dong-Thanh Xuan and Hoai Duc - Tu Liem districts.

We demonstrate that the origin of this phenomenon is a complex combination of the presence of geologic composition of sand, loamy sand, clay with organic matter and sandy clay in the Hai Hung and Thai Binh formations; the development of impermeable built-up surfaces; the lowering of piezometric levels in the $Q_{\mathrm{p}}$ aquifer due to strong withdrawal from $Q_{\mathrm{p}}$ aquifer after 2008, with higher potable water demands accompanying the drawdown of groundwater 
level in the $Q_{\mathrm{h}}$ aquifer; and the choice of foundation type. The temporal evolution of InSAR data compared to leveling data shows a great similarity between these two data sets. A regular lowering of the ground occurred until the end of 2008, and then large variations appear from 2009 with upward- and downward ground motions, which reveal a nonstationary state of the surface deformation. The existence of transient movements of the surface is probably related to the recharge of the aquifer by rainfalls. This study demonstrates that StaMPS/MTI is effective for the region where humanmade structures, such as urban development, are dominant.

The results of this study raise important consequences for hazard management in the Hanoi urban region. A zoning of different levels of land subsidence susceptibility is crucial in order to help find the most appropriate solution. This can be achieved through a combination of groundwater reduction withdrawal, restrained construction work, and suitable building foundations in the most susceptible areas.

Acknowledgements. The authors would like to acknowledge the support of the Vietnam Institute of Geosciences and Mineral Resources under the NAFOSTED grant 105.11.50.09, the Northern Division of Planning and Investigation for Water Resources, the Hanoi Housing and Urban Development Corporation, the Japan Aerospace Exploration Agency, the United States National Aeronautics and Space Administration, the European Space Agency under contract C1P.2616, and the Vietnam Ministry of Education and Training under Project 322. Interferometric data were processed using the open source SAR processor StaMPS.

Edited by: R. Lasaponara

Reviewed by: C. Stewart and one anonymous referee

\section{References}

Alexander, H. and Cheng, D.: Multilayered aquifer systems: fundamentals and applications, Marcel Dekker Inc., New York, 2000.

Amelung, F., Galloway, D., Bell, J., Zebker, H., and Laczniak, R.: Sensing the ups and downs of Las Vegas: InSAR reveals structural control of land subsidence and aquifer-system Geology, 27, 6, 483-486, 1999.

Aobpaet, A., Cuenca, M. C., Hooper, A., and Trisirisatayawong, I.: Land subsidence evaluation using InSAR time series analysis in Bangkok metropolitan area, in: Fringe 2009 Workshop, edited by: Lacoste-Francis, H., Frascati, Italy, 30 November-4 December 2009, s12_16aob, ESA Communications, 2010.

Bell, J. W., Amelung, F., Ramelli, A. R., and Blewitt, G.: Land Subsidence in Las Vegas, Nevada, 1935-2000: New Geodetic Data Show Evolution, Revised Spatial Patterns, and Reduced Rates, Geol. Soc. Am., 8, 155-174, doi:10.2113/8.3.155, 2002.

Berardino, P., Fornaro, G., Lanari, R., and Sansosti, E.: A new algorithm for surface deformation monitoring based on small baseline differential SAR interferograms IEEE T. Geosci. Remote, 40, 2375-2383, 2002.
Bitelli, G. and Russo, P.: Levelling data management for the monitoring of land subsidence, in: Proceedings of Fourth International Symposium on Land Subsidence, edited by: Johnson, A. I., Houston, USA, 12-17 May 1991, 453-462, IAHS Publication, Oxfordshire, 1991.

Bonano, M., Manunta, M., Marsella, M., and Lanari, R.: Long-term ERS/ENVISAT deformation time-series generation at full spatial resolution via the extended SBAS technique, Int. J. Remote Sens., 33, 4756-4783, doi:10.1080/01431161.2011.638340, 2012.

Brambati, A., Carbognin, L., Quaia, T., Teatini, P., and Tosi, L.: The Lagoon of Venice: geological setting, evolution and land subsidence, Episodes, 26, 3, 264-268, 2003.

Bui, D. D., Kawamura, A., Amaguchi, H., Minh, T. T., and Ngoc, T. T.: Recent Trends and Variation in Groundwater Levels of Holocene Unconfined Aquifers in Hanoi, Vietnam, in: The International Synposium Hanoi Geoengineering 2010, edited by: Pham, H. G., Mai, T. N., and Nguyen, H. M., Hanoi, Vietnam, 22-23 Nov 2010, 159-168, Vietnam National University, Ha Noi, 2010.

Bürgmann, R., Rosen, P. A., and Fielding, E. J.: Synthetic aperture radar interferometry to measure Earth's suface topography and its deformation, Earth Planet. Sci., 28, 169-209, 2000.

Carnec, C. and Raucoules, D.: Spécificite du milieu urbain tropical pour la cartographie des deformations de surface par interferometrie RADAR (ERS) - Application au pompage dans les systemes aquiferes a Djakarta et Hanoi, Bulletin - Société française de photogrammétrie et de télédétection, 161, 40-45, 2001.

Cashman, P. M. and Preene, M.: Groundwater lowering in construction: A practical guide, Spon Press, New York, 2002.

Chai, J. C., Shen, S. L., Zhu, H. H., and Zhang, X. L.: 1D analysis of land subsidence in Shanghai, Lowland Technol. Int., 7, 33-41, 2005.

Chen, F., Lin, H., Zhou, W., Hong, T., and Wang, G.: Surface deformation detected by ALOS PALSAR small baseline SAR interferometry over permafrost environment of Beiluhe section, Tibet Plateau, China, Remote Sens. Environ., 138, 10-18, 2013.

Cigna, F., Osmanouglu, B., Cabral-Cano, E., Dixon, T. H., ÁvilaOlivera, J. A., Garduño-Monroy, V. c. H., DeMets, C., and Wdowinski, S.: Monitoring land subsidence and its induced geological hazard with Synthetic Aperture Radar Interferometry: A case study in Morelia, Mexico, Remote Sens. Environ., 117, 146-161, doi:10.1016/j.rse.2011.09.005, 2012.

Crosetto, M., Monserrat, O., and Herrera, G.: Urban applications of Persistent Scatterer Interferometry, in: Radar Remote Sensing of Urban Areas, edited by: Soergel, U., Springer, Hannover, 233$248,2010$.

Crosetto, M., Monserrat, O., Cuevas-Gonzaìlez, M., Devantheìry, N., and Crippa, B.: Analysis of X-band very high resolution Persistent Scatterer Interferometry data over urban area, International Archives of the Photogrammetry, Remote Sensing and Spatial Information Science, Hannover, Germany, 21-24 May 2013, 47-51, 2013.

CWRPI: Yearbook for groundwater ressources of Nothtern Plain in 2010, Center for Water Ressources Planning and Investigation (CWRPI), Hanoi, 2011.

Diem, C. T., Doan, D. N., Tran, N. D., Tran, T. V., Luu, T. A., and Nguyen, D. H.: Report on subsidence observation for CT2 build- 
ing at Van Khe, Ha Dong Vietnam Institute for Building Science and Technology, Ha Noi, 28 pp., 2010.

Dinh, V. M., Hoang, A. T., Cu, T. H., and Hoang, M. T.: Report on measurement of new building in Van Quan ward- Hatay province, HUD-CIC Construction and Investment Consultants Joint Stock Company, Hanoi 35 pp., 2008.

Downing, R. A.: Keynote paper: Falling groundwater levels - a cost-benefit analysis, in: Groundwater Problems in Urban Areas, edited by: Wilkinson, W. B., London, England, 2-3 June 1993, 213-236, Thomas Telford, London, 1994.

Duong, H. A., Berg, M., Hoang, M. H., Pham, H. V., Gallard, H., Giger, W., and Gunten, U. v.: Trihalomethane formation by chlorination of ammonium- and bromide-containing groundwater in water supplies of Hanoi, Vietnam, Water Res., 37, 3242-3252, 2003.

Ferretti, A., Prati, C., and Rocca, F.: Nonlinear subsidence rate estimation using permanent scatterers in differential SAR interferometry, IEEE T. Geosci. Remote, 38, 2202-2212, doi:10.1109/36.868878,2000.

Ferretti, A., Prati, C., and Rocca, F.: Permanent Scatterers in SAR Interferometry, IEEE T. Geosci. Remote, 39, 8-21, 2001.

Fielding, E. J., Blom, R. G., and Goldstein, R. M.: Rapid subsidence over oil fields measured by SAR interferometry, Geophys. Res. Lett., 25, 3215-3218, 1998.

Froese, C. R. and Mei, S.: Mapping and monitoring coal mine subsidence using LiDAR and InSAR, GeoEdmonton'08: 61st Canadian Geotechnical Conference, Edmonton, Canada, 21-24 September, 1127-1133, Canadian Geotechnical Society, 2008.

Galloway, D. L., Hudnut, K. W., Ingebritsen, S. E., Phillips, S. P., Peltzer, G., Rogez, F., and Rosen, P. A.: Detection of aquifer system compaction and land subsidence using interferometric synthetic aperture radar, Antelope Valley, Mojave Desert, California, Water Resour. Res., 34, 2573-2585, 1998.

Galloway, D. L., Jones, D. R., and Ingebritsen, S. E.: Measuring land subsidence from space: http://pubs.usgs.gov/fs/fs-051-00/ (last access: September 2013), 2000.

Gourmelen, N., Amelung, F., Casu, F., Manzo, M. R., and Lanari, R.: Mining-related ground deformation in Crescent Valley, Nevada: Implications for sparse GPS networks, Geophys. Res. Lett., 34, L09309, doi:10.1029/2007GL029427, 2007.

GSO: Population and population density by province in 2009 : http://www.gso.gov.vn/default.aspx?tabid=387\\&idmid=3\ \&ItemID=9865 (last access: 6 March 2013), 2009.

Ha, H. V.: Report on application of remote sensing method for fault investigation supporting soft soil study at Hanoi city, University of Geology and Mining, Hanoipp., 2004.

Haase, D.: Effects of urbanisation on the water balance - A longterm trajectory, Environ. Impact Assess. Rev., 29, 211-219, 2009.

Hoffmann, J., Zebker, H. A., Galloway, D. L., and Amelung, F.: Seasonal subsidence and rebound in Las Vegas Valley, Nevada, observed by synthetic aperture radar interferometry, Water Resour. Res., 37, 551-1566, 2001.

Holzer, T. L.: Man-Induced Land Subsidence, Geological Society of America, Boulder, 221 pp., 1984.

Holzer, T. L. and Galloway, D. L.: Impact of land subsidence caused by withdrawal of underground fluids in the United States, in: Humans as geologic agents, edited by: Ehlen, J., Haneberg, W. C., and Larson, R. A., The Geological Society of America, Boulder, 87-99, 2005.

Hooper, A.: A multi-temporal InSAR method incoporating both persistent scatterer and small baseline approaches, Geophys. Res. Lett., 35, L16302, doi:10.1029/2008GL034654, 2008.

Hooper, A., Zebker, H., Segall, P., and Kampes, B.: A new method for measuring deformation on volcanoes and other natural terrains using InSAR persistent scatterers, Geophys. Res. Lett., 31, L23611, doi:10.1029/2004GL021737, 2004.

Hooper, A., Segall, P., and Zebker, H.: Persistent scatterer interferometric synthetic aperture radar for crustal deformation analysis, with application to Volcan Alcedo, Galapagos, J. Geophys. Res., 112, B07407, doi:10.1029/2006JB004763, 2007.

Hooper, A., Bekaert, D., Spaans, K., and Arıkan, M.: Recent advances in SAR interferometry time series analysis for measuring crustal deformation, Tectonophysics, 514-517, 1-13, 2012.

Ikehara, M. E.: Global Positioning System surveying to monitor land subsidence in Sacramento Valley, California, USA, J. Sci. Hydrol., 39, 417-430, 1994.

Ireland, R. L., Poland, J. F., and Riley, F. S.: Land Subsidence in the San Joaquin Valley, California as of 1980, US, Geological Survey Professional, Washington, 193 pp., 1984.

Johnson, A. I.: A quarter century of IAHS/UNESCO technology transfer regarding land subsidence occurrence and research, in: Fifth International Symposium on Land subsidence, edited by: Barends, F. B. J., Brouwer, F. J. J., and Schroder, F. H., Hague, The Netherlands, 16-20 October 1995, ix-x, IAHS Publication, Oxfordshire, 1995.

Jusseret, S., Baeteman, C., and Dassargues, A.: The stratigraphical architecture of the quaternary deposits as support for hydrogeological modelling of the central zone of Hanoi, Geologica Belgica, 13, 77-90, 2010.

Kampes, B. M.: Radar Interferometry: Persistent Scatterer Technique, Springer, Dordrescht, 211 pp., 2005.

Kim, J.-S., Kim, D.-J., Kim, S.-W., Won, J.-S., and Moon, W. M.: Monitoring of urban land surface subsidence using PSInSAR, Geosci. J., 11, 59-73, doi:10.1007/BF02910381, 2007.

Labbé, D.: Facing the urban transition in Hanoi: recent urban planning issues and initiatives, Institut national de la recherche scientifique, Montréal, 2010.

Lanari, R., Mora, O., Manunta, M., Mallorqui, J., Berardino, P., and Sansosti, E.: A small-baseline approach for investigating deformations on full-resolution differential SAR interferograms, IEEE T. Geosci. Remote, 42, 1377-1386, doi:10.1109/TGRS.2004.828196, 2004.

Lanari, R., Casu, F., Manzo, M., and Lundgren, P.: Application of the SBAS-DInSAR technique to fault creep: a case study of the Hayward fault, California, Remote Sens. Environ. J., 109, 20-28, 2007.

Lanari, R., Berardino, P., Bonano, M., Casu, F., Manconi, A., Manunta, M., Manzo, M., Pepe, A., Pepe, S., Sansosti, E., Solaro, G., Tizzani, P., and Zeni, G.: Surface displacements associated with the L'Aquila $2009 \mathrm{Mw} 6.3$ earthquake (central Italy): New evidence from SBAS-DInSAR time series analysis, Geophys. Res. Lett., 37, L20309, doi:10.1029/2010GL044780, 2010.

Lazecky, M., Jirankova, E., and Bohmova, D.: Usage of InSAR techniques to detect and monitor terrain subsidence due to mining activities, GeoSci. Eng., LVI, 4, 32-49, 2010. 
Lin, H., Chen, F., and Zhao, Q.: Land deformation monitoring using coherent target-neighbourhood networking method combined with polarimetric information: a case study of Shanghai, China, Int. J. Remote Sens., 32, 2395-2407, 2011.

López-Quiroz, P., Doin, M.-P., Tupin, F., Briole, P., and Nicolas, J.M.: Timeseries analysis of MexicoCity subsidence constrained by radar interferometry, J. Appl. Geophys., 69, 1-15, 2009.

Luu, T. N. M., Garnier, J., Billen, G., Orange, D., Némery, J., Le, T. P. Q., Tran, H. T., and Le, L. A.: Hydrological regime and water budget of the Red River Delta (Northern Vietnam), J. Asian Earth Sci., 37, 219-228, 2010.

Lyons, S. and Sandwell, D.: Fault creep along the southern San Andreas from interferometric synthetic aperture radar, permanent scatterers, and stacking, J. Geophys. Res.-Sol. Ea., 108, 2047, doi:10.1029/2002jb001831, 2003.

Massonnet, D. and Feigl, K. L.: Radar interferometry and its application to changes in the Earth's surface, Rev. Geophys., 36, 441-500, 1998.

Massonnet, D., Holzer, T., and Vadon, H.: Land subsidence caused by the East Mesa Geothermal Field, California, observed using SAR interferometry, Geophys. Res. Lett., 24, 901-904, 1997.

Mathers, S. and Zalasiewicz, J.: Holocen Sedimentary Architecture of the Red River Delta, Vietnam, J. Coast. Res., 15, 314-325, 1999.

Mays, L. W.: Integrated Urban Water Management: Arid and SemiArid Regions, edited by: Maksimović, Č. and Tejada-Guibert, A., CRC Press, London, 2009.

Montangero, A., Cau, L. N., Anh, N. V., Tuan, V. D., Nga, P. T., and Belevi, H.: Optimising water and phosphorus management in the urban environmental sanitation system of Hanoi, Vietnam, Sci. Total Environ., 384, 55-66, 2007.

Morris, B. L., Lawrence, A. R. L., Chilton, P. J. C., Adams, B., Calow, R. C., and Klinck, B. A.: Groundwater and its Susceptibility to Degradation: A Global Assessment of the Problem and Options for Management, United Nations Environment Programme, Nairobi, 2003.

NARENCA: Administrative map of Hanoi City, Natural Ressources and Environment Cartography Publishing House, Ha Noi, 2009.

NARENCA: Construction projects in Hanoi City, Natural Ressources and Environment Cartography Publishing House, Hanoi, 2010.

National-Research-Council: Mitigating Losses from Land Subsidence in the United States, National Academy Press, Washington, 1991.

Nguyen, D. D.: Geological map of Hanoi City, Northern Division of Planning and Investigation for Water Resources, Hanoi, 1996a.

Nguyen, D. D.: Report on investigation of urban geology for Hanoi city, Department of Hydrogeology 2, Hanoi, 1996b.

Nguyen, H. P.: Mapping the distribution of soft soil for sustainable development of Hanoi city, Hanoi University of Geology and Mining, Hanoi, 2005

Nguyen, N. M.: Review and analysis of Hanoi land subsidence monitoring data, M.Sc thesis, School of Engineering and Technology, Asian Institute of Technology, Bangkok, 140 pp., 2007.

Nguyen, Q. K.: Results of geological engineering investigation for Commercial Center Duoi Ca, Thinh Liet ward, Hoang Mai district Union of Geological Engineering Investigation and Foundation, Hanoi, 2009.
Nguyen, Q. T., and Helm, D. C.: Land subsidence due to groundwater withdrawal in Hanoi, Vietnam, in: Fifth International Symposium on Land Subsidence, edited by: Barends, F. B. J., Brouwer, F. J. J., and Schroder, F. H., Hague, the Netherlands, 16-20 October 1995, 55-60, IAHS Publication, Oxfordshire, 1995.

Nguyen, T. H. and Nguyen, V. D.: 2006 Yearbook of groundwater resources at Vietnam's Northern Plain, Center for Water Investigation and Planning, Ha Noi, 314 pp., 2007.

Nguyen, T. H. and Nguyen, V. D.: 2007 Yearbook of groundwater resources at Vietnam's Northern Plain, Center for Water Investigation and Planning, Ha Noi, 314 pp., 2008.

Nguyen, T. H. and Pham, Q. D.: 2008 Yearbook of groundwater resources at Vietnam's Northern Plain Center for Water Investigation and Planning, Ha Noi, 315 pp., 2009.

Nguyen, T. H. and Pham, Q. D.: 2009 Yearbook of groundwater resources at Vietnam's Northern Plain Center for Water Investigation and Planning, Ha Noi, 318 pp., 2010.

Nguyen, T. H., Dang, H. H., Vu, T. H. N., and Hoang, T. t. H.: 2010 Yearbook of groundwater resources at Vietnam's Northern Plain Center for Water Investigation and Planning, Ha Noi, 328 pp., 2011.

Noel, A.: Apport de l'interférométrie radar dans la gestion des risques naturels: Cas de Hanoi, Vietnam, Master thesis, Faculté des Science, Université de Liège, Liège, 106 pp., 2008.

Peltzer, G., Crampé, F., Hensley, S., and Rosen, P.: Transient strain accumulation and fault interaction in the Eastern California shear zone Geology, 29, 975-978, 2001.

Poland, J. F.: Guidebook to studies of land subsidence due to groundwater withdrawal, Unesco, Paris, 1984.

PPJ, VIAP, and HUPI: Hanoi Master Plan to 2030 and vision to 2050, Ha Noi's Department of Planning and Architecture, Hanoi, 196 pp., 2011.

Rau, J. L., Nutalaya, P., Tran, V. H., and Nguyen, Q. T.: The problems of land subsidence in the world and in Vietnam, Second conference on Geology of Indochina, Hanoi, Vietnam, 11-13 November 1991, 421-428, Geological Survey of Vietnam, Ha Noi, 1991

Raucoules, D. and Carnec, C.: DEM derivation and subsidence detection on Hanoi from ERS SAR, FRINGE99- Advancing ERS SAR Interferometry from applications towards operations, Liege, Belgium, 10-12 November 1999, on CDROM, ESA Publications Division, 1999.

Samsonov, S.: Topographic Correction for ALOS PALSAR Interferometry, IEEE Geosci. Remote Sens. Lett., 40, 3020-3027, 2010.

Schmidt, D. A., and Bürgmann, R.: Time-dependent land uplift and subsidence in the Santa Clara valley, California, from a large interferometric synthetic aperture radar data set, J. Geophys. Res.Sol. Ea., 108, 2416, doi:10.1029/2002JB002267, 2003.

Shanahan, P.: Groundwater in the Urban Environment, in: The Water Environment of Cities, edited by: Baker, L. A., Springer, New York, 29-48, 2009.

Snelting, H., and Bruchem, A. J. v.: The role of land subsidence and damage to buildings in the selection of suitable sites for groundwater extraction, in: Third International Symposium on Land Subsidence, edited by: Johnson, A. I., Carbognin, L., and Ubertini, L., Venice, Italy, 19-25 March 1984, 767-775, IAHS Publication, 1986. 
Stramondo, S., Bozzano, F., Marra, F., Wegmuller, U., Cinti, F. R., Moro, M., and Saroli, M.: Subsidence induced by urbanisation in the city of Rome detected by advanced InSAR technique and geotechnical investigations, Remote Sens. Environ., 112, 31603172, 2008.

Takeuchi, S. and Yamada, S.: Comparison of InSAR Capability for Land Subsidence Detection between C-band and L-band SAR International Geoscience and Remote Sensing Symposium, Toronto, Canada, 24-28 June 2002, 2379-2381, IEEE Publications, Piscataway, 2002.

Tanabe, S., Saito, Y., Vu, Q. L., Hanebuth, T. J. J., Ngo, Q. L., and Kitamura, A.: Holocene evolution of the Song Hong (Red River) delta system, northern Vietnam, Sediment. Geol., 187, 29-61, 2006.

Tong, N. T., Tran, H. T., Nguyen, T. H., Nguyen, T. H., Dinh, T. T., and Dang, H. N.: Investigated results for arsenic groundwater level in Hanoi city, Northern Hydrogeological Engineering Geological Division, Hanoi, 2001.

Tran, V. A.: Synthetic aperture radar interferometry for DEM generation and subsidence detection over Hanoi city, Vietnam, Docteur thesis, Department of GeoScience, University of Osaka, Osaka, 102 pp., 2007.

Trinh, M. T. and Fredlund, D. G.: Modelling subsidence in the Hanoi city area, Can. Geotech. J., 37, 621-636, 2000.

Tung, H. and Hu, J.-C.: Assessments of serious anthropogenic land subsidence in Yunlin County of central Taiwan from 1996 to 1999 by Persistent Scatterers InSAR, Tectonophysics, 578, 126$135,2012$.
UNESCO: Urban water management, UNESCO, Paris, 2006.

VET: Go West, Vneconomiy, monthly, April, 20-21, Vietnam Economic Times, Hanoi, 2008.

Vöge, M.: Subsidence Estimation Over the City of Hanoi using SAR Interferometry, NGI, Oslo, 2011.

Watson, K. M., Bock, Y., and Sandwell, D. T.: Satellite interferometric observations of displacements associated with seasonal groundwater in the Los Angeles basin, J. Geophys. Res.-Sol. Ea., 107, 2074, doi:10.1029/2001JB000470, 2002.

Wei, M., and Sandwell, D. T.: Decorrelation of L-band and Cband Interferometry over Vegetated Areas in California, IEEE T. Geosci. Remote, 48, 1-11, 2010.

Yan, Y., Doin, M. P., Lopez-Quiroz, P., Tupin, F., Fruneau, B., Pinel, V., and Trouve, E.: Mexico City Subsidence Measured by InSAR Time Series: Joint Analysis Using PS and SBAS Approaches, IEEE J. Sel. Top. Appl., 5, 1312-1326, doi:10.1109/JSTARS.2012.2191146, 2012.

Zebker, H. A. and Villasenor, J.: Decorrelation in Interferometric Radar Echoes IEEE T. Geosci. Remote, 30, 950-959, 1992.

Zebker, H. A., Rosen, P. A., and Hensley, S.: Atmospheric effects in interferometric synthetic aperture radar surface deformation and topographic maps, J. Geophys. Res., 102, 7547-7563, 1997.

Zhen-Dong, C. and Ya-Jie, J.: Study on the mechanisms of the soil consolidation and land subsidence caused by the high-rise building group in the soft soil area, Disaster Adv., 5, 604-609, 2012. 